\title{
A Human Monoclonal IgG That Binds A $\beta$ Assemblies and Diverse Amyloids Exhibits Anti-Amyloid Activities In Vitro and In Vivo
}

\author{
Yona Levites, ${ }^{1}$ Brian 0’Nuallain, ${ }^{2}$ Rama Devudu Puligedda, ${ }^{3}$ Tomas Ondrejcak, ${ }^{4}$ Sharad P. Adekar, ${ }^{3}{ }^{\mathbb{C}}$ Cindy Chen, ${ }^{3}$ \\ Pedro E. Cruz, ${ }^{1}$ Awilda M. Rosario, ${ }^{1}$ Sallie Macy, ${ }^{5}$ Alexandra J. Mably, ${ }^{2}$ Dominic M. Walsh, ${ }^{2}$-Ruben Vidal, ${ }^{6}$ \\ Alan Solomon, ${ }^{5}$ @Daniel Brown, ${ }^{7}$ Michael J. Rowan, ${ }^{4}$ Todd E. Golde, ${ }^{1}$ and ${ }^{\circledR}$ Scott K. Dessain ${ }^{3}$ \\ ${ }^{1}$ Department of Neuroscience, Center for Translational Research in Neurodegenerative Disease, College of Medicine, University of Florida, Gainesville, \\ Florida 32610, ${ }^{2}$ The Laboratory of Neurodegenerative Research, Brigham and Women's Hospital, Harvard Institutes of Medicine, Boston, Massachusetts \\ 02115, ${ }^{3}$ Lankenau Institute for Medical Research, Wynnewood, Pennsylvania 19096, ${ }^{4}$ Trinity College Institute of Neuroscience and Department of \\ Pharmacology and Therapeutics, Trinity College, Dublin 2, Ireland, ${ }^{5}$ University of Tennessee Graduate School of Medicine, Knoxville, Tennessee 37920, \\ ${ }^{6}$ Department of Pathology and Laboratory Medicine and the Indiana Alzheimer Disease Center, Indiana University School of Medicine, Indianapolis, \\ Indiana 46202, and 7Department of Pathology and Laboratory Medicine, Lehigh Valley Health Network, Allentown, Pennsylvania 18103
}

Alzheimer's disease (AD) and familial Danish dementia (FDD) are degenerative neurological diseases characterized by amyloid pathology. Normal human sera contain IgG antibodies that specifically bind diverse preamyloid and amyloid proteins and have shown therapeutic potential in vitro and in vivo. We cloned one of these antibodies, $3 \mathrm{H} 3$, from memory B cells of a healthy individual using a hybridoma method. $3 \mathrm{H} 3$ is an affinity-matured IgG that binds a pan-amyloid epitope, recognizing both A $\beta$ and $\lambda$ Ig light chain (LC) amyloids, which are associated with $\mathrm{AD}$ and primary amyloidosis, respectively. The pan-amyloid-binding properties of $3 \mathrm{H} 3 \mathrm{were}$ demonstrated using ELISA, immunohistochemical studies, and competition binding assays. Functional studies showed that $3 \mathrm{H} 3$ inhibits both $\mathrm{A} \beta$ and LC amyloid formation in vitro and abrogates disruption of hippocampal synaptic plasticity by AD-patient-derived soluble $\mathrm{A} \beta$ in vivo. A $3 \mathrm{H} 3$ single-chain variable fragment $(\mathrm{scFv})$ retained the binding specificity of the $3 \mathrm{H} 3 \mathrm{IgG}$ and, when expressed in the brains of transgenic mice using an adeno-associated virus (AAV) vector, decreased parenchymal A $\beta$ amyloid deposition in TgCRND8 mice and ADan (Danish Amyloid) cerebral amyloid angiopathy in the mouse model of FDD. These data indicate that naturally occurring human IgGs can recognize a conformational, amyloid-specific epitope and have potent anti-amyloid activities, providing a rationale to test their potential as antibody therapeutics for diverse neurological and other amyloid diseases.

Key words: Alzheimer's disease; amyloid; amyloid beta; animal study; antibody; IVIG

\section{Introduction}

Alzheimer's disease (AD) and Familial Danish dementia (FDD) are degenerative neurological diseases characterized by the depo-

Received Dec. 16, 2014; revised Feb. 10, 2015; accepted Feb. 12, 2015.

Author contributions:Y.L., B.O.'N, R.D.P., T.O., S.P.A., C.C., S.M., D.M.W., R.V., A.S., D.B., M.J.R., T.E.G., and S.K.D. designed research; Y.L., B.O.'N, R.D.P., T.O., S.P.A., C.C., P.E.C., A.M.R., S.M., and A.J.M. performed research; R.V. and D.B. contributed unpublished reagents/analytic tools;Y.L., B.O.'N, R.D.P., T.O., and S.K.D. analyzed data; Y.L., B.O.'N, R.D.P., D.M.W., M.J.R., T.E.G., and S.K.D. wrote the paper.

This work was supported by Sharpe-Strumia Research Foundation (S.K.D.), the Edward N. and Della Thome Memorial Foundation (T.G. and S.K.D.), NIH Grant AG18454 (T.G.), and Science Foundation Ireland (M.J.R.). The content is solely the responsibility of the authors and does not necessarily represent the official views of the National Institutes of Health. We thank Gordon Freeman (Dana Farber/Partners Cancer Care) for the tCD40L cell line, Brenda D. Moore for preparing and characterizing various generic amyloids and fibrillar A $\beta$, Chandana Devi Kattala for laboratory assistance, and Gwen Gilliard with help with the brain IHC. Human tissues used in Figure 2, $m-t$, were obtained from the University of Florida Neuromedicine Human Brain Tissue Bank.

S.K.D. has stock ownership in a company (Immunome, Inc.) that has licensed the human monoclonal antibody cloning method and the $3 \mathrm{H} 3$ antibody described here. He and S.P.A. are also inventors on patents related to the hybridoma method. The remaining authors declare no competing financial interests.

This article is freely available online through the J Neurosci Author Open Choice option.

Correspondence should be addressed to either of the following: Scott K. Dessain, Lankenau Institute for Medical Research, 100 Lancaster Ave., Wynnewood, PA 19096, E-mail dessains@mlhs.org; or Yona Levites, Department of sition of pathological amyloids. Amyloid deposits and inclusions are characterized by the accumulation of normally soluble proteins in insoluble fibrillar forms. They adopt a characteristic amyloid conformation, which is highly enriched for $\beta$-pleated sheets and exhibits green birefringence under polarized light when stained with Congo red. Soluble preamyloid structures have also been identified, which include both oligomers with relatively little $\beta$-pleated sheet structure and protofibrils (PFs) that have a high degree of $\beta$-pleated sheet structure. In $\mathrm{AD}, \mathrm{A} \beta$ oligomers may be more toxic than amyloid fibrils (Lambert et al., 1998; Walsh et al., 2002).

$\mathrm{AD}$ and FDD are examples of $>30$ human amyloid diseases that range from common disorders such as $\mathrm{AD}$ to rare autosomal disorders such as FDD (Chiti and Dobson, 2006). These diseases produce amyloid proteins with entirely different sequences that

Neuroscience, CTRND, College of Medicine, University of Florida, 1275 Center Drive, P.0. Box 100159, Gainesville, FL 32610, E-mail: levites.yona@ufl.edu.

DOI:10.1523/JNEUROSCI.5109-14.2015

Copyright $\odot 2015$ the authors $\quad 0270-6474 / 15 / 356265-12 \$ 15.00 / 0$ 
share conformational epitopes resulting from their $\beta$-pleated sheet structure (Kayed et al., 2003). Monoclonal antibodies (mAbs) have been isolated that recognize these pan-amyloid conformers and have anti-amyloid activities (Hrncic et al., 2000; O'Nuallain and Wetzel, 2002; O'Nuallain et al., 2011; Zhang et al., 2011; Zhao et al., 2014). Human intravenous Ig's (IVIGs) derived from pools of plasma from healthy donors contain IgGs that bind these epitopes ( $\mathrm{Du}$ et al., 2001; Du et al., 2003; O'Nuallain et al., 2006). We reported that A $\beta$-reactive polyclonal IgGs in IVIGs cross-reacted with different types of amyloid fibrils and oligomers, including Ig light chain amyloid (AL) (O'Nuallain et al., 2006; O'Nuallain et al., 2008). These antibodies impaired $\mathrm{A} \beta$ and $\mathrm{AL}$ fibrillogenesis in vitro and dissociated $\mathrm{AL}$ amyloid in vivo. Experiments testing IVIG in transgenic AD mouse models suggested that short-term or long-term treatments can benefit cognitive function (Mengel et al., 2013; St-Amour et al., 2014). Results of clinical testing of IVIG in mild to moderate AD patients have been mixed, but a randomized trial suggested cognitive benefits for moderate $\mathrm{AD}$ patients and APOE- $\varepsilon 4$ carriers (Relkin, 2014).

These data support the hypothesis that conformation-specific human IgGs exist and may have useful anti-amyloid properties. However, it is not clear whether the conformational amyloid binding and anti-amyloid capabilities observed with polyclonal IVIGs can be replicated by individual mAbs or if these may contribute to the potential utility of IVIG in AD (Relkin et al., 2009; Magga et al., 2010; Sudduth et al., 2013; Gu et al., 2014).

Here, we report on the cloning, characterization, and functional properties of an anti-amyloid IgG isolated from memory B cells of a healthy subject using a hybridoma method. This IgG $\mathrm{mAb}, 3 \mathrm{H} 3$, recognized diverse amyloids, inhibited elongation of $\mathrm{A} \beta$ and LC amyloids, and reduced the disruption of synaptic plasticity in the rat hippocampus by $\mathrm{AD}$ brain extract. Expression of a single-chain variable fragment ( $\mathrm{scFv}$ ) derived from $3 \mathrm{H} 3$, attenuated $\mathrm{A} \beta$ amyloid deposition in the brains of TgCRND8transgenic mice and cerebral amyloid angiopathy (CAA) from ADan deposition in a mouse model of FDD. This study supports further investigation of the clinical utility of naturally occurring human mAbs that recognize conformational amyloid epitopes.

\section{Materials and Methods}

Proteins and polypeptides. Human A $\beta 40$ and S26C A $\beta 40$, a mutant A $\beta 40$ containing a cysteine in place of serine 26 , which enables the formation of a disulfide cross-linked dimer, [S26C A $\beta 40]_{2}$ (O’Nuallain et al., 2010), were purchased from Quality Controlled Biochemicals. Wild-type (WT) $\mathrm{A} \beta 40$ monomers, monomeric S26C A $\beta 40$, [S26C A $\beta 40]_{2},[\mathrm{~S} 26 \mathrm{CA} \beta]_{2 \mathrm{PFs}}$, and $\mathrm{A} \beta 40$ fibrils were generated as below and were used immediately or frozen at $-80^{\circ} \mathrm{C}$. WT and S26C peptide concentrations were determined by absorbance at $275 \mathrm{~nm}$ using the molar extinction coefficient for tyrosine at $275 \mathrm{~nm}\left(\mathrm{e}_{275}=1400 \mathrm{M}^{-1} \mathrm{~cm}^{-1}\right)$.

Before use, the lyophilized $\mathrm{A} \beta 40$ was disaggregated by sequential exposure to trifluoroacetic acid and hexafluoroisopropanol (Thermo Fisher) followed by the addition of $2 \mathrm{~mm} \mathrm{NaOH}$ and $2 \times \mathrm{PBS}(1 \times$ final $)$ and ultracentrifuged to give a final peptide concentration of $\sim 0.2 \mathrm{mg} / \mathrm{ml}$ (O'Nuallain et al., 2006). [S26C A $\beta 40]_{2}$ was prepared by solubilizing the S26C A $\beta 40$ peptide to $\sim 0.2 \mathrm{mg} / \mathrm{ml}$ in MilliQ water (Millipore), diluted $1: 1$ with $20 \mathrm{~mm}$ ammonium bicarbonate, $\mathrm{pH} 8.2$, to generate an $\sim 20 \mu \mathrm{M}$ (with respect to monomer) peptide solution, and bubbled with oxygen for $\sim 5-10 \mathrm{~min}$. The peptide was incubated at room temperature for $\sim 3$ $\mathrm{d}$ and each day bubbled with oxygen.

WT and S26C A $\beta 40$ monomers and [S26C A $\beta 40]_{2}$ were isolated from different sized $A \beta 40$ assemblies using size exclusion chromatography. Peptides were incubated in $50 \mathrm{~mm}$ Tris- $\mathrm{HCl}$ containing $6 \mathrm{~m}$ guanidine $\mathrm{HCl}, \mathrm{pH} 8.0$, to dissociate preexisting aggregates and then characterized on a HiLoad 16/60 Superdex 75 column (GE Healthcare Bio-Sciences) eluted at $0.8 \mathrm{ml} / \mathrm{min}$ in $25 \mathrm{~mm}$ ammonium acetate, $\mathrm{pH} 8.5$ (O'Nuallain et al., 2010). Fractions that contained $A \beta 40$ monomers or $[S 26 \mathrm{C} \mathrm{A} \beta 40]_{2}$ were analyzed by SDS-PAGE using $16 \%$ polyacrylamide Tris-tricine gels and silver staining (Shevchenko et al., 1996).

Meta-stable thioflavin T (ThT)-positive PFs were generated by diluting freshly isolated $[\mathrm{S} 26 \mathrm{C} \mathrm{A} \beta 40]_{2}$ to $\sim 0.1 \mathrm{mg} / \mathrm{ml}$ in $20 \mathrm{~mm}$ sodium phosphate, $\mathrm{pH} 7.4$, and incubating the reaction mixture for $\sim 3 \mathrm{~d}$ at $37^{\circ} \mathrm{C}$ (O'Nuallain et al., 2010). The reaction was monitored by ThT fluorescence and was judged complete when the fluorescent signal reached a maximum plateau value (LeVine, 1999). Formation of PFs was confirmed by electron microscopy and by the presence of ThT-positive aggregates in reaction supernatants after centrifugation at $16,000 \times g$ for $20 \mathrm{~min}$.

JTO is a recombinant amyloidogenic $\lambda 6 \mathrm{LC}$ variable region cloned from a multiple myeloma patient (Wall et al., 1999). JTO was produced in an E. coli expression system and purified as described previously (Wall et al., 1999). The soluble LC was sterile-filtered using a $0.22 \mu \mathrm{m}$ polyvinylidene fluoride $25 \mathrm{~mm}$ Millex-GV syringe-driven filter unit (Millipore) and shown to be $>90 \%$ pure, consisting of monomers and dimers using Sephadex G25 (GE Healthcare) gel filtration and SDS-PAGE. The protein concentration was determined by the MicroBCA assay (Thermo Fisher).

WT A $\beta 40$ and JTO fibrils were generated by incubating $0.2 \mathrm{mg} / \mathrm{ml}$ concentrations of the amyloidogenic proteins in PBS containing $0.02 \%$ sodium azide, $\mathrm{pH} 7.4$, at $37^{\circ} \mathrm{C}$ for $14 \mathrm{~d}$ [23]. Fibrillogenesis was judged complete when ThT fluorescence reached maximum plateau values. The reaction products were harvested by centrifugation at $20,200 \times g$ for 30 min at room temperature and fibril morphology confirmed by negative contrast electron microscopy.

Amyloid fibrils derived from $\mathrm{AL}$ patient tissues and $\mathrm{AD}$ patient brain plaque cores have been described previously (O'Nuallain et al., 2007; O’Nuallain et al., 2008).

Cloning and initial characterization of $3 \mathrm{H} 3 \mathrm{mAb}$. The $3 \mathrm{H} 3 \mathrm{mAb}$ was cloned following previously described methods (Adekar et al., 2008b). Work with human peripheral blood cells was performed under a protocol approved by the Main Line Hospitals Institutional Review Board and consistent with the principles set out in the WMA Declaration of Helsinki and the National Institutes of Health Belmont Report. After receipt of informed consent, a blood sample from a healthy adult male was collected in heparin containing tubes. Peripheral blood mononuclear cells (PBMCs) were isolated by gradient density centrifugation with FicollPaque Plus (GE Healthcare). PBMCs were stored frozen in $90 \%$ heat-inactivated fetal calf serum (Life Technologies) and 10\% DMSO (Sigma-Aldrich) under liquid nitrogen. Before cell fusion, $\mathrm{CD} 27^{+}$cells were isolated with antiCD27 magnetic beads (Miltenyi Biotec) according to the manufacturer's instructions and cultured for $8 \mathrm{~d}$ on a monolayer of tCD40L cells (Urashima et al., 1995) (courtesy of Gordon Freeman, Dana Farber/ Partners Cancer Care) in IMDM supplemented with $10 \%$ human $\mathrm{AB}$ serum, IL-4, IL-10, transferrin, gentamycin, insulin, and cyclosporine. On day 8, cultured $\mathrm{CD} 27^{+}$cells were electrofused to the B5-6T heteromyeloma cell line (Adekar et al., 2008a), plated in 96-well plates, and selected in HAT medium (Sigma-Aldrich).

Hybridoma supernatants were screened by ELISAs with $\mathrm{A} \beta 40$ or JTO fibrils bound to 96 -well high binding (Corning) plates at $4^{\circ} \mathrm{C}$ overnight with $100 \mu \mathrm{l} /$ well at $5 \mu \mathrm{g} / \mathrm{ml}$ in PBS. Specific IgG was detected with the HRP-conjugated anti-human IgG monoclonal antibody (9040-05) (Southern Biotechnology). Hybridoma supernatants that were positive in ELISA were selected for subcloning by limiting dilution. After 3 rounds of subcloning, stable hybridomas were adapted to serum-free medium (IS MAB-CD; Irvine Scientific), incubated for $5 \mathrm{~d}$ in a $500 \mathrm{ml}$ roller bottle. Filtered supernatants were purified over protein G-Sepharose (GE Healthcare). Purity was assessed by SDS-PAGE (Life Technologies) and shown to be $>90 \%$ pure. Protein concentrations were determined using the NanoDrop spectrophotometer (NanoDrop Technologies).

IgG heavy-chain (HC) and LC subtypes were assessed by capture of the antibodies with a polyclonal rabbit anti-human whole IgG (6145-01; Southern Biotech) and identification of reactivity with the HRPconjugated mouse anti-human IgG3 monoclonal antibody (053620; Life Technologies) and the $\lambda$ LC-specific HRP-conjugated goat anti-human 
polyclonal antibody (2070-05; Southern Biotech), respectively. For all ELISAs, $o$-phenylenediamine was used as the colorimetric substrate; optical density at $490 \mathrm{~nm}$ was measured using a BioTek ELISA reader.

Variable domain cDNA sequences of the $3 \mathrm{H} 3 \mathrm{mAb}$ were amplified with consensus primer sets specific for human Ig heavy chains (Campbell et al., 1992) and for $\lambda$ light chains (Coronella et al., 2000), as previously described (Adekar et al., 2008b). DNA fragments were sequenced by the Kimmel Cancer Center Nucleic Acid Facility, Thomas Jefferson University (Philadelphia, Pennsylvania) and analyzed using the V-Quest program (Lefranc et al., 2005).

Direct and competitive assays of antibody binding to amyloids. Antibody reactivity with wild-type A $\beta 40$ fibrils, S26C A $\beta 40$ monomers, [S26C $\mathrm{A} \beta 40]_{2}$, monomeric $\mathrm{A} \beta 40$, bovine elastin fibrils (Sigma-Aldrich), JTO, and patient-derived $\mathrm{A} \beta$ fibrils and LC amyloids was determined using a europium $\left(\mathrm{Eu}^{+}{ }^{+}\right.$)-based fluoroimmunoassay (EuLISA) (Adekar et al., 2010). The EuLISA was performed with purified $3 \mathrm{H} 3$ in assay buffer $(1 \%$ BSA in PBSA containing $0.05 \%$ Tween 20 ) in activated high-binding Costar microtiter plate wells coated with $400 \mathrm{ng}$ of target protein and blocked with $1 \%$ BSA (Sigma-Aldrich) in PBS. A biotinylated goat antihuman $\operatorname{IgG}$ ( $\gamma$-chain specific; Sigma-Aldrich) served as the secondary antibody. After the addition of a Eu $3^{+}$streptavidin conjugate, followed by the releasing enhancement solution, $\mathrm{Eu} 3^{+}$time-resolved fluorescence was measured using a Victor2 1420 Multilabel Counter (PerkinElmer). The amount (fM) of lanthanide released was calculated from a standard curve using known concentrations of $\mathrm{Eu} 3^{+}$. All measurements were done in triplicate (error bars in the figures represent SD) and antibody half-maximal effective concentration $\left(\mathrm{EC}_{50}\right)$ values were determined from the sigmoidally fit binding curves (SigmaPlot 2000 ver. 8; Systat Software).

For the competition binding studies, we used the $\mathrm{Eu} 3^{+}$time-resolved fluoroimmunoassay (Diamandis, 1988) incorporating Eu3 ${ }^{+}$-streptavidin and time-resolved fluorometry (DELFIA system; PerkinElmer) as described previously (O'Nuallain et al., 2006). Ninety-six-well plates were coated with $400 \mathrm{ng}$ of soluble or fibrillar protein or peptide and blocked with $1 \%$ BSA in PBSA. The concentration of the antibody remained constant in the presence up to a 100- to 50-fold molar excess of soluble protein or peptide or $0.5-0.1 \mathrm{mg} / \mathrm{ml}$ fibrillar competitors. Biotinylated goat anti-human IgG (Sigma-Aldrich) served as the secondary antibody. Time-resolved fluorescence was measured as described above. Halfmaximal inhibitory concentration $\left(\mathrm{IC}_{50}\right)$ values were determined by fitting each titration dataset to a sigmoid equation using the SigmaPlot 2000 version 8 software package (Systat Software).

Human tissue samples and immunohistochemistry. Human brain samples, including pathologically confirmed $\mathrm{AD}$ cases, were obtained at autopsy, fixed in formalin, embedded in paraffin blocks, and sliced into 4- to 6- $\mu \mathrm{m}$-thick slices and placed on poly-L-lysine coated microscope slides. Antigen retrieval was with Vecta stain antigen retrieval solution (Vector Labs), boiled in a pressure cooker for $30 \mathrm{~min}$, blocked for $30 \mathrm{~min}$ at $37^{\circ} \mathrm{C}$, developed with the Vector $\mathrm{ABC}$ kit (Vector Labs) and 3,3'diaminobenzidene, followed by counterstaining with hematoxylin. Staining of human kidney, heart, and spleen samples from patients with amyloid deposition was performed on 4 - to $6-\mu \mathrm{m}$-thick sections cut from formalin-fixed, paraffin-embedded blocks of amyloid-laden tissue and placed on poly-L-lysine coated microscope slides for Congo red and antibody staining. Antigen retrieval was performed by $30 \mathrm{~min}$ boiling in Glyca solution (BioGenex). Tissues were exposed overnight at $4^{\circ} \mathrm{C}$ to 0.1 $\mu \mathrm{g} / \mathrm{ml}$ biotinylated $3 \mathrm{H} 3 \mathrm{mAb}$ in HEPES-buffered saline. Slides were developed using a Vectastain $\mathrm{ABC}$ kit (Vector Labs) and 3,3'-diaminobenzidene and examined with a Leica DM500 microscope.

Inhibition of fibril formation. To assay the formation of amyloid fibrils in real time, we used ThT fluorescence to measure amyloid fibril formation in solution (Ban et al., 2003). Wells of an ultra-low-binding 96-well plate (Corning) were filled with $15 \mu \mathrm{M}$ soluble $\mathrm{A} \beta 40$ or $50 \mu \mathrm{M}$ JTO monomer, $30 \mu \mathrm{M}$ ThT, and serial dilutions of the test antibodies (1.0 $\mu \mathrm{M}-10 \mathrm{~nm}$ ) in PBS containing $10 \mu \mathrm{M}$ ThT, pH 7.4 (Adekar et al., 2008b). The plates were incubated at $37^{\circ} \mathrm{C}$ and fluorescence intensity was measured hourly for $5 \mathrm{~h}$ with the FL600 microplate reader.

Measurement of $3 \mathrm{H} 3$ binding kinetics. Off-rate screening and affinity determination were performed on an Octet RED384 instrument (Pall
ForteBio). All measurements were performed at $30^{\circ} \mathrm{C}$; 96 -well microplates were agitated at $1000 \mathrm{rpm}$. Various $3 \mathrm{H} 3$ or pan- $\mathrm{A} \beta$ antibody dilutions in a range of $10 \mathrm{nM}$ to $1 \mathrm{~mm}$ were prepared in a new 384-well microtiter plate for secondary screening. Monomeric $A \beta 40$ or $A \beta 42$ were biotinylated using EZ-Link sulfo-NHS-LC-biotin (Thermo Fisher) according to the manufacturer's protocol and immobilized at a concentration of $50 \mu \mathrm{g} / \mathrm{ml}$ on streptavidin sensors for 10 minutes. For off-rate screening, sensors were blocked with $1 \%$ bovine serum albumin (SigmaAldrich) for $5 \mathrm{~min}$, transferred to the wells containing the antibody dilution for the association step ( $5 \mathrm{~min}$ ), and transferred back to the blocking well for the measurement of the dissociation step ( $5 \mathrm{~min})$. Dissociation rate constants $\left(k_{\text {off }}\right)$ for each antibody concentration were calculated applying a 1:1 interaction model (fitting local, full) using the ForteBio data analysis software 7.0.1.5. Curves that could not be reliably fitted with the software (mostly full $R^{2}<0.96$ ), presumably due to heterogeneous binding, were excluded from the analysis.

In vivo electrophysiology measurements of long-term potentiation. Experiments were performed on groups of five to seven urethaneanesthetized adult male Lister hooded rats, and were licensed by the Department of Health and Children, Ireland. Single pathway recordings of field EPSPs from the stratum radiatum in the CA1 area of the hippocampus were evoked by stimulation of the ipsilateral Schaffer collateral-commissural pathway (Klyubin et al., 2004). Test EPSPs were evoked at a frequency of $0.033 \mathrm{~Hz}$ and at a stimulation intensity adjusted to trigger an EPSP amplitude of $50 \%$ of maximum. The high-frequency stimulation (HFS) protocol for inducing long-term potentiation (LTP) consisted of 10 trains of 20 stimuli, interstimulus interval of $5 \mathrm{~ms}(200$ $\mathrm{Hz}$ ), intertrain interval of $2 \mathrm{~s}$. The stimulation intensity during the HFS remained unchanged. To inject samples, a cannula was implanted in the lateral cerebral ventricle (coordinates $1 \mathrm{~mm}$ lateral to the midline and 4 $\mathrm{mm}$ below the surface of the dura) just before electrode implantation. The preparation of the soluble $\mathrm{AD}$ brain extract and $\mathrm{AD}$ brain extract immunodepleted of $A \beta$ used in the present experiments has been described previously (Hu et al., 2014) and was obtained and used in accordance with local institutional review board guidelines. For the intracerebral coinjection paradigm, either $3 \mathrm{H} 3$ or the control antibody was coincubated with the human $\mathrm{AD}$ brain extract for $10 \mathrm{~min}$ at room temperature before the mixture was injected.

LTP is expressed as the mean \pm SEM percent baseline field EPSP amplitude recorded over a $45 \mathrm{~min}$ baseline period. Statistical analysis (GraphPad Prism version 6 for PC) comparing LTP values at 3 h postHFS was performed using one-way ANOVA followed by Holm-Sidak's multiple-comparisons post hoc tests.

Construction of a $3 \mathrm{H} 3 \mathrm{scFv}$ and expression in adeno-associated virus $(A A V) .3 \mathrm{H} 3 \mathrm{scFv}$ cDNA was synthesized at Blue Heron Biotechnology based on $\mathrm{mAb} \mathrm{HC}$ and $\mathrm{LC}$ variable domain sequences in $\mathrm{V}_{\mathrm{H}}$-linker- $\mathrm{V}_{\mathrm{L}}$ orientation and separated by a $\mathrm{Gly}_{4} \mathrm{Ser}_{3}$ linker. The $\mathrm{scFv}$ was cloned into the pSecTag plasmid under control of the cytomegalovirus enhancer and chicken $\beta$-actin (CBA) promoter with an Ig $\kappa$ secretion leader at the $\mathrm{N}$ terminus and c-Myc and 6xHIS tags at the $\mathrm{C}$ terminus, a Woodchuck hepatitis virus posttranscriptional regulatory element, and the bovine growth hormone polyA sequence (Levites et al., 2006a). Nonspecific scFv ( $\mathrm{scFv} n s$ ) was obtained from a phage library (Medical Research Council) and showed no affinity to $\mathrm{A} \beta$.

rAAV2/1 was prepared by standard methods. Briefly, pAAVs expressing the $\mathrm{scFv}$ were generated by transfection of the vector plasmid with helper plasmids for serotype 1 in HEK293T cells (Levites et al., 2006a). Forty-eight hours after transfection, cells were harvested and lysed in the presence of $0.5 \%$ sodium deoxycholate and $50 \mathrm{U} / \mathrm{ml}$ benzonase (SigmaAldrich) by freeze thawing; the virus was isolated using a discontinuous iodixanol gradient and affinity purified on a HiTrap HQ column (GE Healthcare). The genomic titer of each virus was determined by quantitative PCR.

HEK cells were transfected with pSecTag scFv or pAAV scFv. Conditioned media were collected $48 \mathrm{~h}$ later and cells were lysed in $1 \%$ Triton $\mathrm{X}-100$ with protease inhibitors. Media and cells were then subjected to SDS-PAGE Western blotting analysis with chicken anti-c-myc (1:1000; Invitrogen) as primary antibody. When expression was confirmed, media from transfected cells was analyzed by direct ELISA method 
with $\mathrm{A} \beta$ fibrils ( $100 \mathrm{ng} /$ well) as capture and anti-c-myc-HRP (1:2000) as detection.

Animal studies of $r A A V 2 / 1$ expression. Animal husbandry procedures were performed as approved by University of Florida Institutional Animal Care and Use Committee in an AAALAC-approved facility in accordance with National Institutes of Health guidelines. To generate TgCRND8 mice, male TgCRND8 mice containing double mutation in human APP gene (KM670/671NL and V717F; Chishti et al., 2001) were mated with female B6C3F1/Tac that were obtained from Taconic. Genotyping was performed by PCR as described previously (Levites et al., 2006b). Tg-ADan mice (TgFDD) and genotyping have been described previously (Vidal et al., 2009). All animals were housed three to five to a cage and maintained on ad libitum food and water with a $12 \mathrm{~h} \mathrm{light/dark}$ cycle.

Injection of neonatal mice was performed based on Chakrabarty et al. (2013). Briefly, P0 pups were cryoanesthetized on ice for $5 \mathrm{~min} .2 \mu \mathrm{l}$ of rAAV2/1-scFv were injected intracerebroventricularly (ICV) into the both hemispheres using a $10 \mu$ l Hamilton syringe with a 30 g needle. The pups were then placed on a heating pad with their original nesting material for 3-5 min and returned to their mother for further recovery. For adult injections, mAb $3 \mathrm{H} 3(500 \mu \mathrm{g}, 1 \mathrm{mg} / \mathrm{ml})$ was administered though intraperitoneal injection to TgCRND8 mice.

Analysis of $A \beta$ or ADan in the brain. Biochemical and immunohistochemical analyses of $A \beta$ in the brains of transgenic TgCRND8 and ADan mice were performed as described previously (Levites et al., 2006a; Levites et al., 2006c). The following $\mathrm{mAbs}$ against $\mathrm{A} \beta$ were used in the sandwich capture ELISA for brain $A \beta 40$ : monoclonal pan- $A \beta$ antibody $\mathrm{mAb} 5$ for capture and $\mathrm{A} \beta 40$-specific $\mathrm{mAb} 40.1-\mathrm{HRP}$ for detection (Levites et al., 2006b). For brain $A \beta 42$, we used $A \beta 42$-specific $m A b 42.2$ for capture and mAb5-HRP for detection (Levites et al., 2006b). At the time of killing, the brains of mice were divided by midsagittal dissection and the first hemibrain was used for biochemical analysis. Each hemibrain was sequentially extracted in a 3-step procedure with RIPA followed by SDS followed by formic acid (FA) (Levites et al., 2006b).

Immunohistochemical staining was done using pan- $\mathrm{A} \beta$ antibody 33.1.1 (1:1500) (Kim et al., 2007), glial fibrillary acidic protein (GFAP; 1:500; Millipore), anti-c-Myc (1;500; Life Technologies). The second hemibrains were fixed in $4 \%$ paraformaldehyde in $0.1 \mathrm{M} \mathrm{PBS}, \mathrm{pH} 7.6$, and then dissected and stained for visualization of $\mathrm{A} \beta$ plaques ( $\mathrm{pan}-\mathrm{A} \beta \mathrm{mAb}$ 33.1.1, 1:500; Todd Golde), ADan deposits (rabbit polyclonal antibody 1700, 1:500; Ruben Vidal), GFAP (1:500; Millipore), Iba-1 (1:1000; Wako Chemicals). For cerebrovascular amyloid detection, paraffin sections were stained with $1 \%$ Thio-S (Sigma-Aldrich).

Quantitation of $\mathrm{A} \beta$ plaque burden and intensity of astrogliosisassociated staining were calculated using the Positive Pixel Count program (Aperio Technologies). At least three sections per sample, $30 \mu \mathrm{m}$ apart, were averaged by a blinded observer to calculate plaque burden. For Thio-S quantitation, three sections per sample were used to count the plaques or to calculate total positive pixel count using respective algorithms. All of the above analyses were performed in a blinded fashion. One-way ANOVA, followed by Dunnett's multiple-comparison test, were performed using the scientific statistic software Prism (version 3; GraphPad Software). $p$-values $<0.05$ were considered significant.

\section{Results}

\section{Binding of $3 \mathrm{H} 3$ to oligomeric $\mathrm{A} \boldsymbol{\beta}$ and LC fibrils}

We performed a cell fusion using peripheral blood B cells obtained from a healthy male in his 30s. Hybridomas secreting human IgG were screened for binding to $A \beta 42$ amyloid and an amyloid formed from a recombinant LC variable domain $\lambda 6$ (JTO) (Wall et al., 1999). The IgG3 $\lambda$ mAb 3H3 was cloned and bound both antigens (data not shown). DNA sequence analysis of the variable domains revealed a HC complementarity determining region 3 (CDR3) length of 22 aa with $3.9 \%$ aa changes from germline and an LC CDR3 length of 10 aa with $4.0 \%$ aa changes. These features are typical of the antibodies produced by $\mathrm{CD} 27^{+}$ memory B cells circulating in peripheral blood (Klein et al., 1998).

We tested the binding of the $3 \mathrm{H} 3$ to $\mathrm{A} \beta 40$ conformers using an europium ELISA with plate-immobilized wild-type $\mathrm{A} \beta 40 \mathrm{fi}-$ brils, $\mathrm{A} \beta 40$ monomers, S26C A $\beta 40$ dimers ( $[\mathrm{S} 26 \mathrm{C} \mathrm{A} \beta 40]_{2}$ ), and S26C A $\beta 40$ monomers, generated by $\beta$-mercaptoethanol reduction of the dimeric peptide (Fig. $1 a$ ). S26C A $\beta 40$ is a synthetic $\mathrm{A} \beta$ peptide (1-40) containing cysteine in place of serine 26 , which can form a disulfide cross-linked dimer (O'Nuallain et al., 2010). The binding curves demonstrated that the $3 \mathrm{H} 3 \mathrm{mAb}$ has nanomolar reactivity with plate-immobilized $\mathrm{A} \beta$ conformers and $\sim 2$ fold weaker binding to the monomeric peptide. Calculated $\mathrm{EC}_{50}$ values were as follows: WT fibrils, $6.0 \pm 0.02 \mathrm{nM}$, WT monomers, $17 \pm 0.05 \mathrm{nM}$, [S26C A $\beta 40]_{2}, 6.0 \pm 0.04 \mathrm{nM}$, and S26C A $\beta 40$ monomers, $9.1 \pm 0.06 \mathrm{~nm}$. A control, nonbinding $\mathrm{mAb}(30 \mathrm{~B})$, which binds serotype $\mathrm{B}$ botulinum neurotoxin (Adekar et al., 2008b), showed essentially no reactivity with $[\mathrm{S} 26 \mathrm{C} \mathrm{A} \beta 40]_{2}\left(\mathrm{EC}_{50}>300 \mathrm{~nm}\right)$.

Because $A \beta 40$ conformations may be altered by binding to the ELISA plate (O'Nuallain et al., 2007), we compared 3H3 binding to soluble $\mathrm{A} \beta 40$ aggregates using a competition binding ELISA (Fig. $1 b$ ). We bound [S26C A $\beta 40]_{2}$ to the plate and added $3 \mathrm{H} 3$ $\mathrm{mAb}$ in the presence of each of the following competitors: $\mathrm{A} \beta 40$ fibrils, A $\beta 40$ monomers, [S26C A $\beta 40]_{2}$, or S26C A $\beta 40$ PFs. Binding of the $3 \mathrm{H} 3$ to the plate-immobilized $[\mathrm{S} 26 \mathrm{C} \mathrm{A} \beta 40]_{2}$ was inhibited only by aggregated $\mathrm{A} \beta$ and not by $\mathrm{A} \beta$ monomers, with the strongest inhibition provided by $\mathrm{A} \beta 40$ fibrils and $\mathrm{PFs}$. The calculated $\mathrm{IC}_{50}$ values were $\mathrm{A} \beta 40$ fibrils: $0.62 \pm 0.03 \mu \mathrm{g} / \mathrm{ml},[\mathrm{S} 26 \mathrm{C}$ $\mathrm{A} \beta 40]_{2}: 8.4 \pm 3.6 \mu \mathrm{g} / \mathrm{ml}, \mathrm{S} 26 \mathrm{C} \mathrm{A} \beta 40$ PFs: $3.9 \pm 0.28 \mu \mathrm{g} / \mathrm{ml}$, and A $\beta 40$ monomers: $>40 \mu \mathrm{g} / \mathrm{ml}$. We assessed whether $3 \mathrm{H} 3$ bound to elastin fibrils, which do not adopt an amyloid configuration (Fig. 1c), comparing their binding to plate-immobilized $\mathrm{A} \beta 40$ and JTO fibrils. The calculated $\mathrm{EC}_{50}$ values were $\mathrm{A} \beta 40$ fibrils: $15 \pm 0.05 \mathrm{nM}$, LC fibrils: $47 \pm 0.50 \mathrm{nM}$, and elastin fibrils: $>300$ nM. These data indicate that $3 \mathrm{H} 3$ preferentially binds amyloid fibrils and aggregated $\mathrm{A} \beta$ forms. We measured the avidity of $3 \mathrm{H} 3$ antibody to biotinylated fibrillar $A \beta 40$ and $A \beta 42$, loaded onto streptavidin sensors using the ForteBio Octet system (Ylera et al., 2013). The $K_{\mathrm{D}} \mathrm{s}$ for $3 \mathrm{H} 3$ binding to $\mathrm{A} \beta 40$ fibrils $\left(2.00 \times 10^{-10 \mathrm{~m}}\right)$ and $\mathrm{A} \beta 42$ fibrils $\left(1.78 \times 10^{-10 \mathrm{~m}}\right)$ were calculated based on $k_{\text {on }}$ and $k_{\text {off }}$ rates.

\section{Immunohistochemical assessment of $3 \mathrm{H} 3$ binding to diverse amyloids in diseased tissues}

We used ELISA to test whether $3 \mathrm{H} 3$ could bind $\mathrm{A} \beta$ amyloid from $\mathrm{AD}$ patient brains and LC amyloid from AL patients. $3 \mathrm{H} 3$ bound to $\mathrm{AD}$ patient fibrils from congophilic neuritic plaque cores as well as to different LC species isolated from two AL patients, one a $\kappa 1 \mathrm{LC}$ and the other a $\lambda 3 \mathrm{LC}$ (Fig. 1d). Calculated EC $_{50}$ values were AD plaques: $14 \pm 0.05 \mathrm{nM}, \kappa 1$ LC fibrils: $14 \pm 0.15 \mathrm{~nm}$, and $\lambda 3$ LC fibrils: $123 \pm 10 \mathrm{~nm}$, which are comparable to those observed with the synthetic amyloids.

We assessed binding of $3 \mathrm{H} 3$ to pathologic amyloids in brain tissues from patients with neurologic amyloid diseases. $3 \mathrm{H} 3$ bound plaques and blood vessels in the $\mathrm{AD}$ brain (Fig. $2 b, e$ ), but not in normal brain (Fig. $2 a, d$ ). The $30 \mathrm{~B}$ control mAb did not bind any structures in the $\mathrm{AD}$ brain (Fig. $2 c, f$ ). $3 \mathrm{H} 3$ also bound to amyloid deposited in brain tissue of patients with multiple systems atrophy, which is characterized by $\alpha$-synuclein-positive glial cytoplasmic inclusions, $\mathrm{AD}$ with CAA, and progressive supranuclear palsy, with neurofibrillary tangles containing tau, whereas the pooled human IgG control did not bind to these tissues (Fig. $2 m-o$ ). Naturally occurring antibodies in serum that react with $\alpha$-synuclein or A $\beta$ plaques have been described in healthy subjects (Britschgi et al., 2009; Besong-Agbo et al., 2013). $3 \mathrm{H} 3$ also bound to $\mathrm{A} \beta$ plaques deposited in the brains of 
A

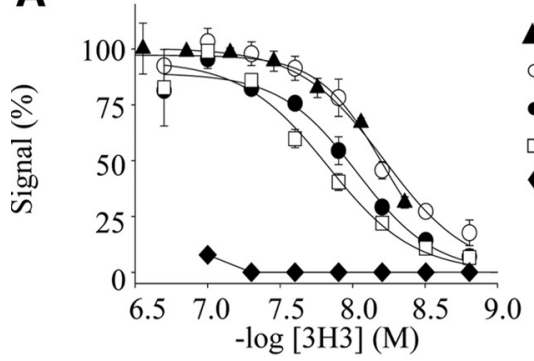

B

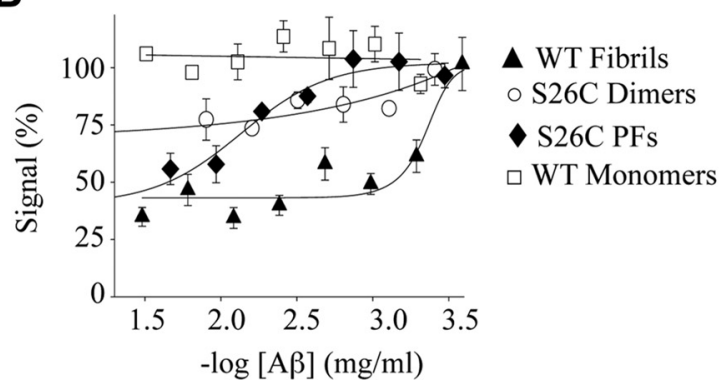

WT Fibrils

- S26C Dimers

$\checkmark$ WT Monomers

- S26C Dimers-

$\mathrm{Ctrl} \mathrm{mAb}$
C

- S26C monomers

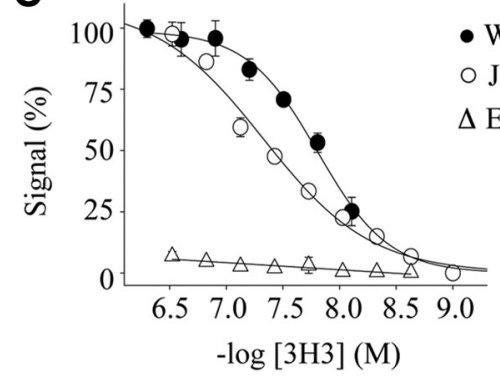

-WT A $\beta$ Fibrils

- JTO (LC) fibrils

$\Delta$ Elastin fibrils

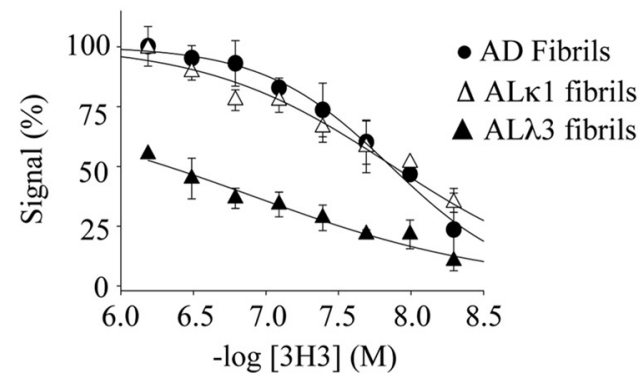

Figure 1. $\mathrm{mAb} 3 \mathrm{H} 3$ is pan-reactive against immobilized $\mathrm{A} \beta$ conformers but in solution only recognizes aggregated peptide. $A$, Antibody binding curves for $3 \mathrm{H} 3$ demonstrate the antibody's low nм reactivity with plate-immobilized $A \beta$ conformers, albeit $\sim 2$-fold weaker binding to the monomeric peptide. $A$ control $\mathrm{mAb}, 30 \mathrm{~B}$, had essentially no reactivity with plate-immobilized $A \beta$. $526 \mathrm{C}$ $\mathrm{A} \beta 40$ monomers were generated by $\beta$-mercaptoethanol reduction of the dimeric peptide. Filled triangles, WT A $\beta 40$ fibrils; open squares, WT A $\beta 40$ monomers; open circles, S26C A $\beta 40$ dimers ( $[526 \mathrm{CA} \beta 40]_{2}$ ) filled circles, $S 26 \mathrm{CA} \beta 40$ monomers; all were tested with the $3 \mathrm{H} 3 \mathrm{mAb}$. Filled diamonds, [S26C A $\left.\beta 40\right]_{2}$, tested for binding of the $30 \mathrm{~B}$ control mAb. $\boldsymbol{B}$, Representative competition ELISA curves are shown for solution-phase $A \beta$ conformer's inhibition of mAb 3H3 binding to plate-immobilized recombinant [S26C A $\beta 40]_{2}$. Filled triangles, WT A 340 fibrils; open circles, [S26C $\mathrm{A} \beta 40]_{2}$; filled diamonds, S26CA $\beta 40 \mathrm{PFs}$; open squares, WT A $\beta 40$ monomers. C, Antibody binding curves for $3 \mathrm{H} 3$ demonstrate the antibody's similar low nu reactivity against plate-immobilized A $\beta$ (filled circles) and recombinant JTO LC amyloid fibrils (open circles), and inability to recognize nonamyloid elastin fibrils (open triangles). The calculated EC ${ }_{50}$ values were $A \beta 40$ fibrils: $15 \pm 0.05 \mathrm{~nm}$, LC fibrils: $47 \pm 0.50 \mathrm{~nm}$, and elastin fibrils: $>300 \mathrm{~nm} . D, 3 \mathrm{H} 3$ binding curves show the antibody's nм reactivity with plate-immobilized patient-derived $\mathrm{A} \beta$ (filled circles), $\kappa 1 \mathrm{LC}$ (open triangles) and $\lambda 3 \mathrm{LC}$ fibrils (filled triangles), with $\mathrm{EC}_{50}$ values of $14 \pm 0.05 \mathrm{~nm}, 14 \pm 0.15 \mathrm{~nm}$ and $123 \pm 10 \mathrm{~nm}$, respectively.
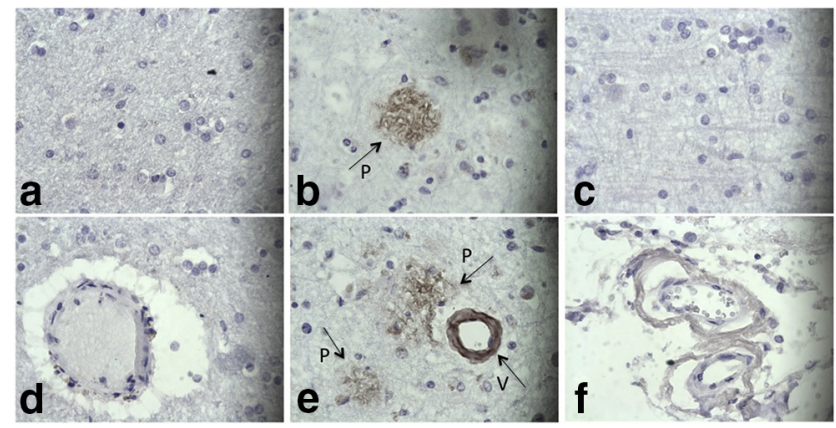

Figure 2. $3 \mathrm{H} 3$ binding to AD brain and AL kidney tissues. Normal $(\boldsymbol{a}, \boldsymbol{d})$ and $\mathrm{AD}$ brains $(\boldsymbol{b}, \boldsymbol{c}$, $\boldsymbol{e}, \boldsymbol{f})$ were stained with $3 \mathrm{H} 3(\boldsymbol{a}, \boldsymbol{b}, \boldsymbol{d}, \boldsymbol{e})$ or the human nonbinding control $\operatorname{lgG} \mathrm{mAb}, 30 \mathrm{~B}(\boldsymbol{c}, \boldsymbol{f})$. Plaques $(\boldsymbol{P})$ and blood vessels $(\boldsymbol{V})$ are shown with arrows. $(400 \times)$. $3 \mathrm{H} 3$ was also tested for binding to kidney samples from a patient with $\kappa 1 \mathrm{LC}$ deposition $(\boldsymbol{g}), \lambda 8 \mathrm{LC}$ deposition $(\boldsymbol{h})$, and a normal subject (i). Pooled human serum IgG did not bind these tissues $(\boldsymbol{j}-\boldsymbol{I})$. $(200 \times)$. $(\boldsymbol{m}-\boldsymbol{t})$ $3 \mathrm{H} 3$ (bottom row) was compared with pooled human IgG (top row) by immunohistochemistry for binding to cortical tissue from patients and-transgenic mice. MSA $(\boldsymbol{m}, \boldsymbol{q})$ Multiple Systems Atrophy $\alpha$-synuclein positive glial cytoplasmic inclusions; CAA $(\boldsymbol{n}, \boldsymbol{r})$ AD with CAA; PSS $(\boldsymbol{o}, \boldsymbol{s})$ Progressive Supranuclear Palsy, tau-containing neurofibrillary tangles, $\operatorname{CRND} 8(\boldsymbol{p}, \boldsymbol{t})$ mouse, the $\operatorname{TgCNRD8}$-transgenic mouse model with $A \beta$ plaques. The brown color indicates binding. Scale bar, $500 \mu \mathrm{m}$, insets $50 \mu \mathrm{m}$.

TgCRND8 mice, which express a mutant (K670N/M671L and V717F) human $\beta \mathrm{APP}_{695}$ transgene (Janus et al., 2000; Fig. 2).

We tested binding of $3 \mathrm{H} 3$ to non-neurological amyloids. The $3 \mathrm{H} 3 \mathrm{mAb}$ bound to kidney samples from PSA patients, one with a $\kappa 1$ LC (Fig. $2 g$ ) and the other a $\lambda 8$ LC (Fig. $2 h$ ), whereas it did not bind to normal kidney (Fig. 2i) and pooled human IgG did not bind to any of these tissues (Fig. $2 j-l$ ). $3 \mathrm{H} 3$ bound cardiac

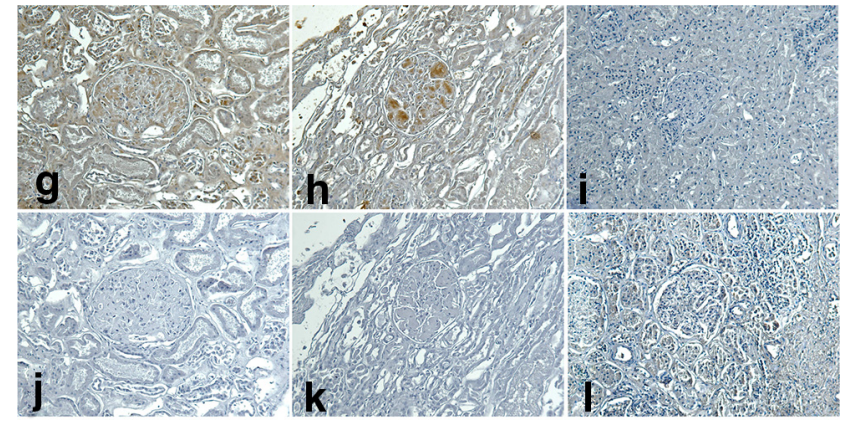

Figure 2. Continued.

tissue affected by transthyretin deposition, as well as pathological $\lambda 1$ amyloid in kidney and $\lambda 3$ amyloid in spleen (data not shown). These data suggest that the $3 \mathrm{H} 3 \mathrm{mAb}$ recognizes an amyloidspecific conformational epitope that is present in amyloids of different primary sequences in diseased tissue.

\section{Inhibition of fibril formation}

Antibody binding to amyloid epitopes can correlate with the ability to interfere with de novo growth (O'Nuallain et al., 2006; Adekar et al., 2010). Therefore, we tested the ability of the $3 \mathrm{H} 3$ $\mathrm{mAb}$ to inhibit elongation of fibrils formed from $\mathrm{A} \beta 40$ or JTO. We first mixed $\mathrm{A} \beta 40$ monomers with ThT, a molecule that fluoresces quantitatively when bound to amyloid fibrils, in the presence of serially diluted $3 \mathrm{H} 3$ or the $30 \mathrm{~B}$ control mAb (Fig. $3 a, b$ ). At the higher $\mathrm{mAb}$ concentrations tested, $0.25-1.0 \mu \mathrm{M}$, the $3 \mathrm{H} 3 \mathrm{in}-$ hibited $\mathrm{A} \beta 40$ fibril elongation, whereas the $30 \mathrm{~B} \mathrm{mAb}$ did not. At the lower concentrations, 0.06 and $0.13 \mu \mathrm{M}$, the time course for 
MSA
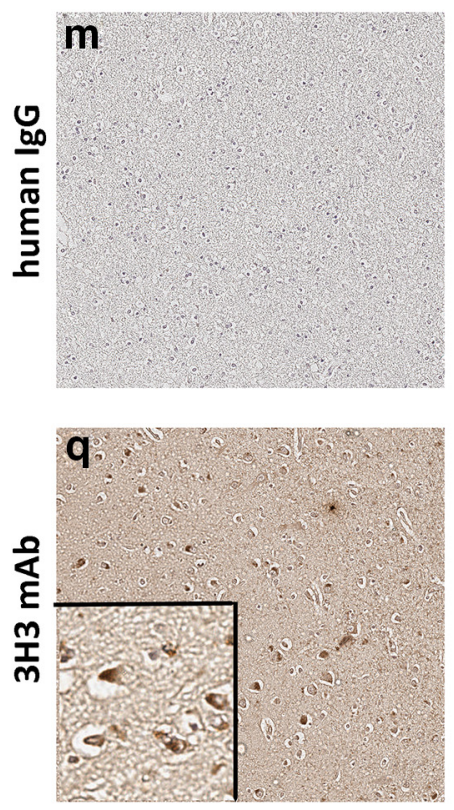

CAA
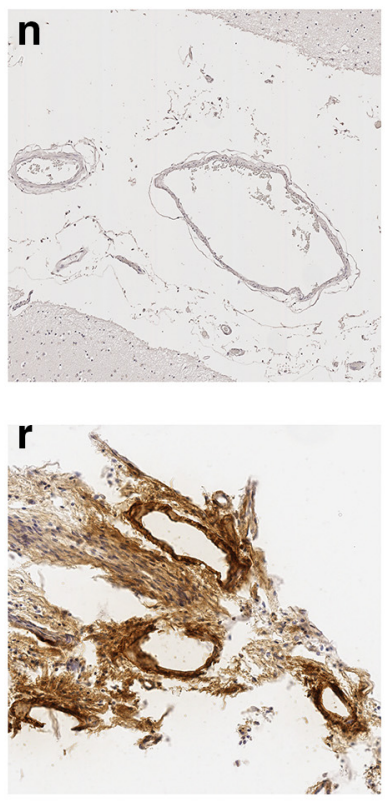

PSP
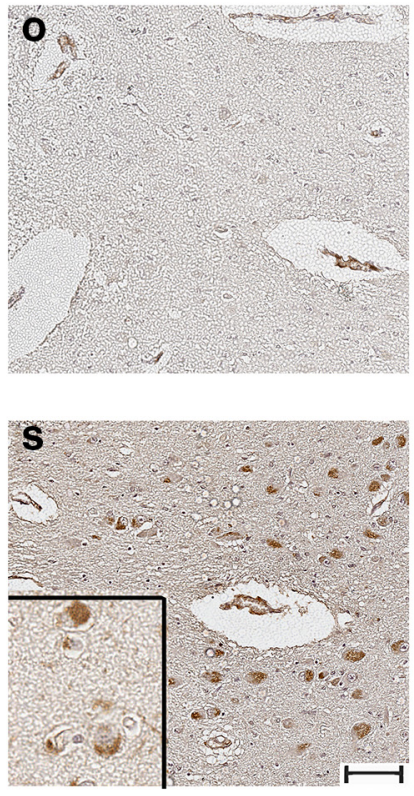

CRND8 mouse
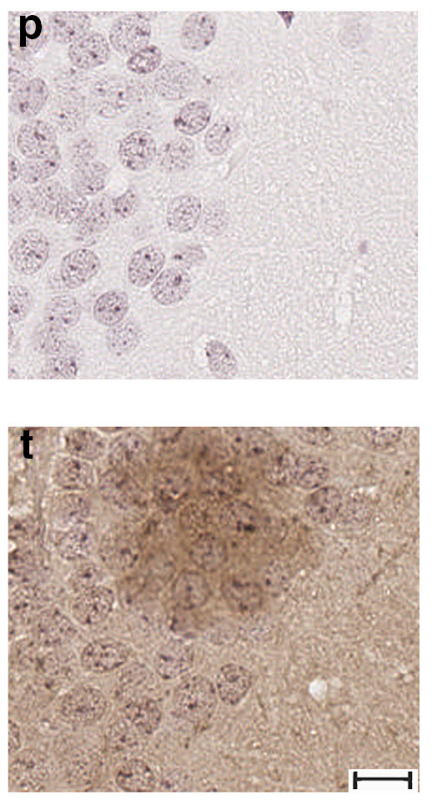

Figure 2. Continued.

A

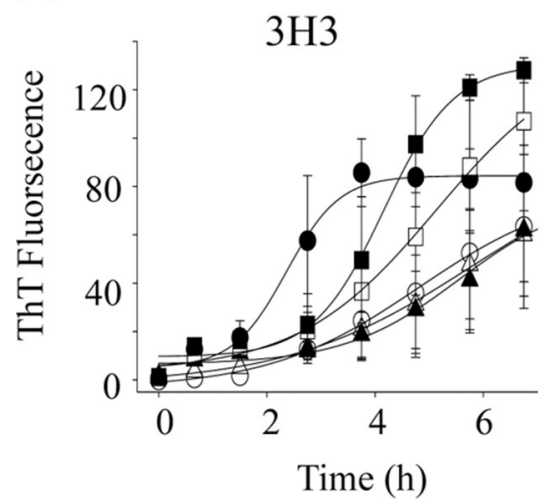

C

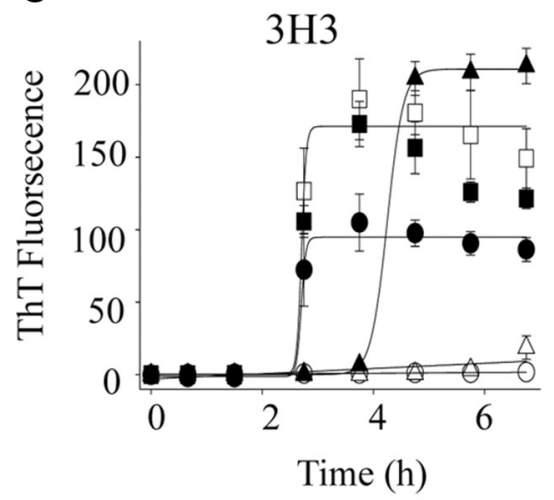

B

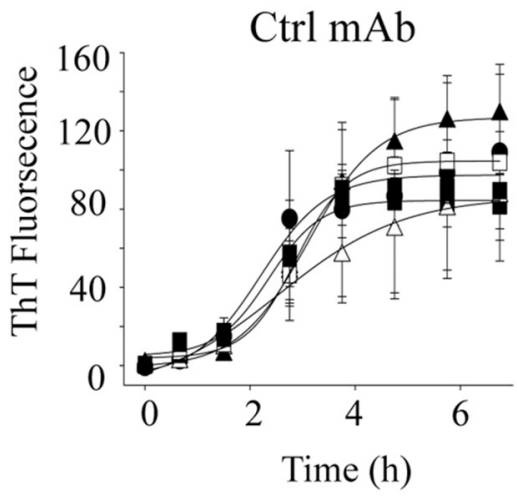

- $\mathrm{A} \beta$ alone

$\circ+1.0 \mu \mathrm{M} \mathrm{mAb}$

$\Delta+0.5 \mu \mathrm{M} \mathrm{mAb}$

$\Delta+0.25 \mu \mathrm{M} \mathrm{mAb}$

$\square+0.13 \mu \mathrm{M} \mathrm{mAb}$

$+0.06 \mu \mathrm{M} \mathrm{mAb}$

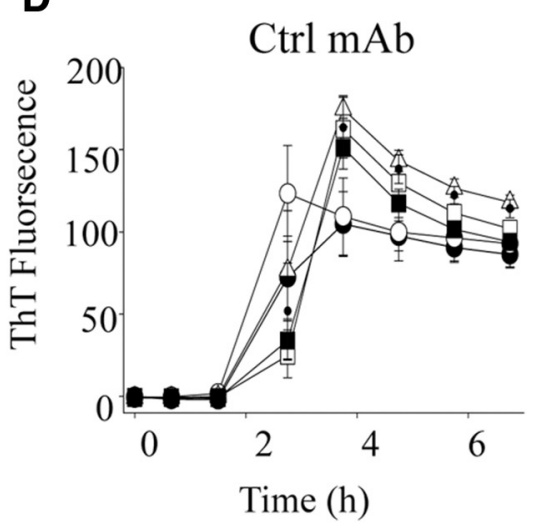

- LC alone

$\circ+1.0 \mu \mathrm{M} \mathrm{mAb}$

$\Delta+0.5 \mu \mathrm{M} \mathrm{mAb}$

$\boldsymbol{\Delta}+0.25 \mu \mathrm{M} \mathrm{mAb}$

$\square+0.13 \mu \mathrm{M} m A b$

- $+0.06 \mu \mathrm{M} \mathrm{mAb}$

Time (h)

Figure 3. Dose-dependent inhibition of de novo $\mathrm{A} \beta$ and $\mathrm{LC}$ amyloid fibril formation by subequimolar $3 \mathrm{H} 3 . \mathrm{A} \beta$ and $\mathrm{LC}$ monomers were incubated in the presence of dilution series of the $3 \mathrm{H} 3$ and $30 \mathrm{~B}$ mAbs. The progress curves for $\mathrm{A} \beta(\boldsymbol{A}, \boldsymbol{B})$ and $\mathrm{LC}(\boldsymbol{C}, \boldsymbol{D})$ amyloid fibril formation show that $3 \mathrm{H} 3$ dose-dependently inhibited the formation of ThT positive amyloidogenic aggregates, whereas the control 30B did not. The aggregation reactions were performed using 15 and $5 \mu \mathrm{m} \mathrm{A} \beta$ monomers and JTO $\lambda \mathrm{LC}$, respectively, in PBS containing $10 \mu \mathrm{m}$ ThT, pH 
fibril formation was delayed, although there was an increase in the total amount of ThT fluorescence relative to the control. Similar results were seen with JTO fibrils (Fig. $3 c, d$ ), with inhibition of fibril growth at 0.5 and $1.0 \mu \mathrm{M}$ and elongation delay at $0.25 \mu \mathrm{M}$, which also gave a greater final level of ThT fluorescence than the control. $3 \mathrm{H} 3$ concentrations of 0.06 and $0.13 \mu \mathrm{M}$ did not alter the rate of ThT uptake by JTO. These findings indicate that the $3 \mathrm{H} 3$ $\mathrm{mAb}$ can inhibit $\mathrm{A} \beta 40$ and JTO fibril growth.

\section{Abrogation of the disruption of hippocampal synaptic plasticity by soluble $\mathrm{A} \beta$ in $\mathrm{AD}$ brain extract in vivo} Intracerebral injection of water-soluble $\mathrm{A} \beta$ oligomers potently inhibits LTP of synaptic transmission in the hippocampus, a neurophysiological correlate of hippocampus-dependent memory (Walsh et al., 2002; Shankar et al., 2008). Here, we assessed the ability of $3 \mathrm{H} 3$ to acutely abrogate the inhibition of LTP by ADpatient-derived soluble $\mathrm{A} \beta$ oligomers at CA3-to-CA1 synapses in the hippocampus of urethane-anesthetized rats (Cullen et al., 1997; Klyubin et al., 2005). Electrically evoked field EPSPs (EPSPs) were recorded for $1 \mathrm{~h}$ before the application of conditioning HFS. Whereas LTP decayed gradually in animals that received an intracerebroventricular injection of soluble $\mathrm{A} \beta$ containing AD brain extract 15 min before HFS, an identical HFS protocol induced a stable, persistent increase in magnitude of CA1 EPSPs in animals that received an injection of the same AD patient brain soluble extract that had been immunodepleted of $\mathrm{A} \beta(p<0.01 \%, 107 \pm 4.3 \%$, and $127.6 \pm 4.5 \%$ of pre-HFS baseline, respectively, at 3 h post-HFS, $n=7$ per group; Fig. $4 a, c)$. The $\mathrm{A} \beta$-containing AD brain extract no longer inhibited LTP ( $119.3 \pm 3.0 \%, n=7, p<0.05$ compared with $\mathrm{AD}$ group) when coadministered with a dose of the $3 \mathrm{H} 3 \mathrm{mAb}$ that did not affect control LTP $(p>0.05$ compared with the immunodepletedalone group, $123.2 \pm 1.3 \%, n=6$; Fig. $4 b, c)$. Coadministration of the same amount of the control $30 \mathrm{~B}$ mAb did not affect the ability of the soluble $\mathrm{A} \beta$ in $\mathrm{AD}$ brain extract to inhibit LTP (106.2 \pm $4.4 \%, n=5$, data not shown). These results suggest that $3 \mathrm{H} 3$ mitigates the disruptive effect of $\mathrm{AD}$-patient-derived, soluble $\mathrm{A} \beta$ oligomers on hippocampal LTP.

\section{Studies of in vivo expression of $3 \mathrm{H} 3 \mathrm{scFv}$ in the TgCRND8 and ADan mice}

We converted the $3 \mathrm{H} 3$ into an $\mathrm{scFv}$ for in vivo expression using the AAV system. Neonatal injection of AAVs into the brains of mice evades the host immune response and enables persistent transgene expression. We cloned the variable regions of the $3 \mathrm{H} 3$ $\mathrm{scFv}$ into the mammalian expression vector pSecTag and the plasmid, which drives expression from the CBA promoter and provides C-terminal c-Myc and 6xHis tags. After transfection of HEK cells with pSecTag-3H3 and pAAV-3H3, analysis of scFv secreted in cell culture media was performed by ELISA in triplicate. Secreted $\mathrm{scFv}$ preferentially bound to $\mathrm{A} \beta$ fibrils relative to monomers in an ELISA: pSecTag-3H3 (OD450 fibrils: $0.354 \pm$ 0.024, OD450 monomer: $0.056 \pm 0.012$ ), pAAV-3H3 (OD450 fibrils: $1.089 \pm 0.067$, OD450 monomer: $0.187 \pm 0.037$ ), pan-Ab scFv9 (OD450 fibrils: $0.542 \pm 0.034$, OD450 monomer: $0.983 \pm$ 0.005; Levites et al., 2006a). This confirms that the $\mathrm{scFv}$ replicated the binding specificity of the intact IgG and suggests that the recognition of $\mathrm{A} \beta$ aggregates by $3 \mathrm{H} 3$ results from canonical Ig binding activity.

Four microliters of a pAAV-3H3 scFv solution $\left(10^{13}\right.$ genomes $/ \mathrm{ml}$ ) was delivered into the cerebral ventricles of newborn TgCRND8 pups. At 5 months, an age by which substantial amyloid pathology typically develops in these mice, we extracted
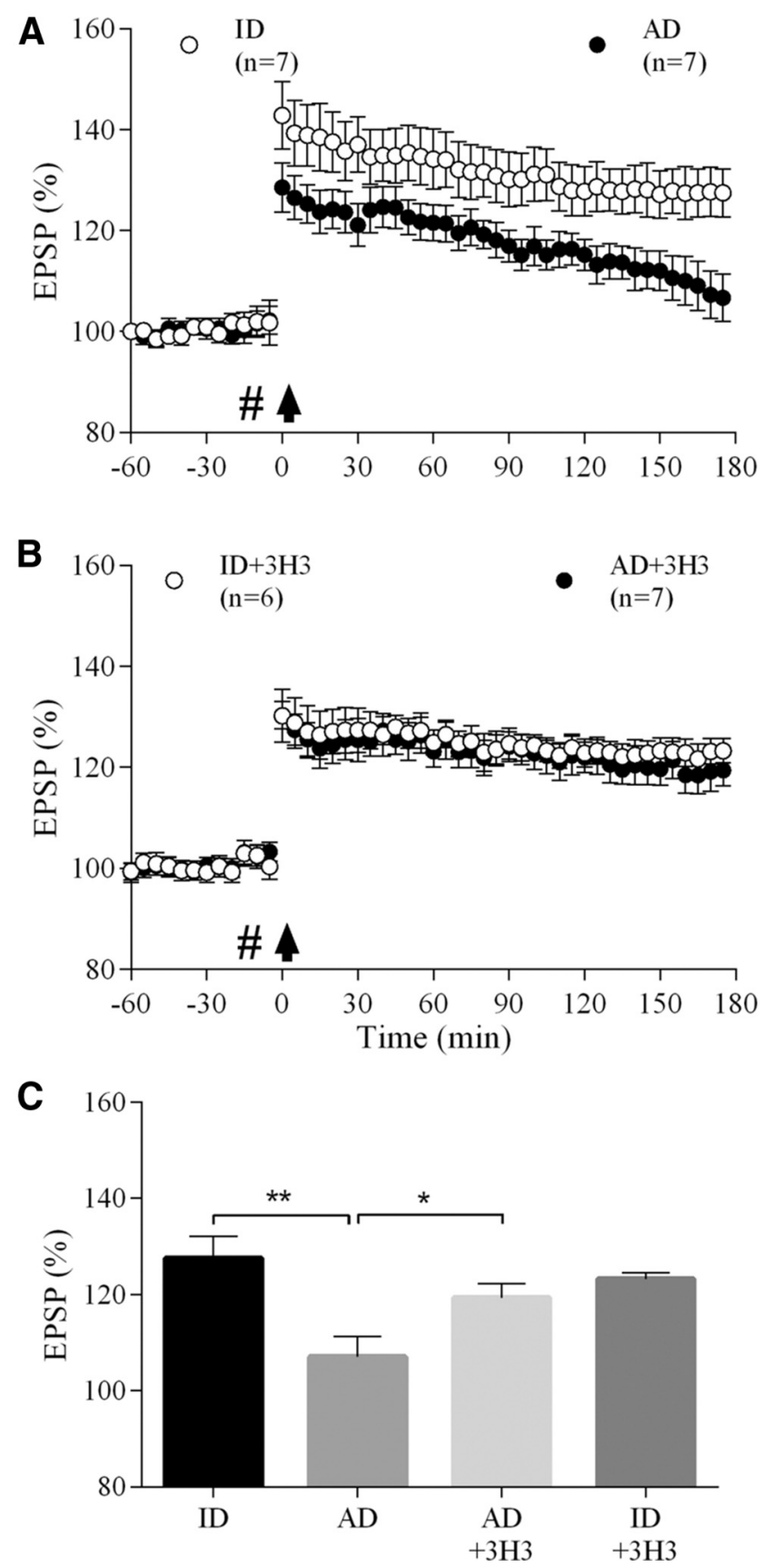

Figure 4. $3 \mathrm{H} 3$ abrogates the disruption of hippocampal synaptic plasticity by soluble $A \beta$ in AD brain extract. $A$, Synaptic field potentials (EPSPS) were recorded from the CA1 area of anesthetized rats. The acute intracerebroventricular injection (\#) of AD brain TBS extract (AD, filled circles, $n=7$ ) 15 min prior high-frequency stimulation (HFS) conditioning (arrow) strongly inhibited LTP compared with brain extract that had been effectively immunodepleted (ID) of all detectable A $\beta$, see (Hu et al., 2014) (ID, open circles, $n=7$ ). B , Coinjection of 3 H3 antibody (10 $\mu \mathrm{g}$ ) prevented the inhibition of $L T P$ by soluble $A \beta$-containing $A D$ brain extract $\left(\mathrm{AD}^{+} 3 \mathrm{H} 3\right.$, closed circles, $n=7)$. When coinjected with ID extract, $3 \mathrm{H} 3$ did not affect LTP $\left(\mathrm{ID}^{+} 3 \mathrm{H} 3\right.$, open circles, $n=6)$. $C$, Summary LTP data at $3 \mathrm{~h}$ post-HFS for all experimental groups shown in $(A, B)$. ${ }^{*} p<0.05$ and ${ }^{* *} p<0.01$. Values are mean \pm SEM.

brains and processed them for immunohistochemical and biochemical analysis. We evaluated scFv expression in the brains of the injection group using the anti-c-Myc antibody (Fig. $5 a-c)$. All mice in this group had widespread brain expression of the scFv, particularly in the hippocampus and cortex. We assessed the effects of $3 \mathrm{H} 3 \mathrm{scFv}$ expression on $\mathrm{A} \beta$ plaque deposition. We stained 


\section{Expression}

\section{PBS}

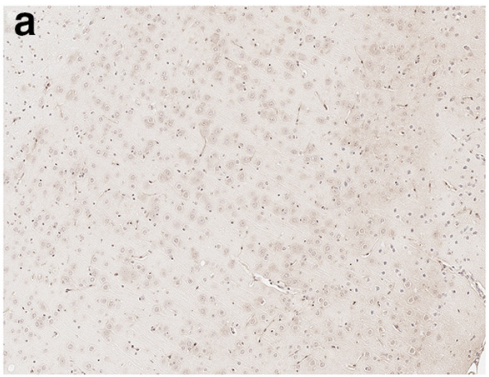

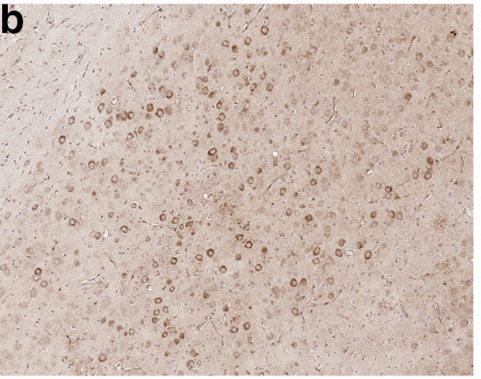

$3 \mathrm{H} 3 \mathrm{scFv}$

\section{Amyloid plaques}

\section{H3 ScFv}
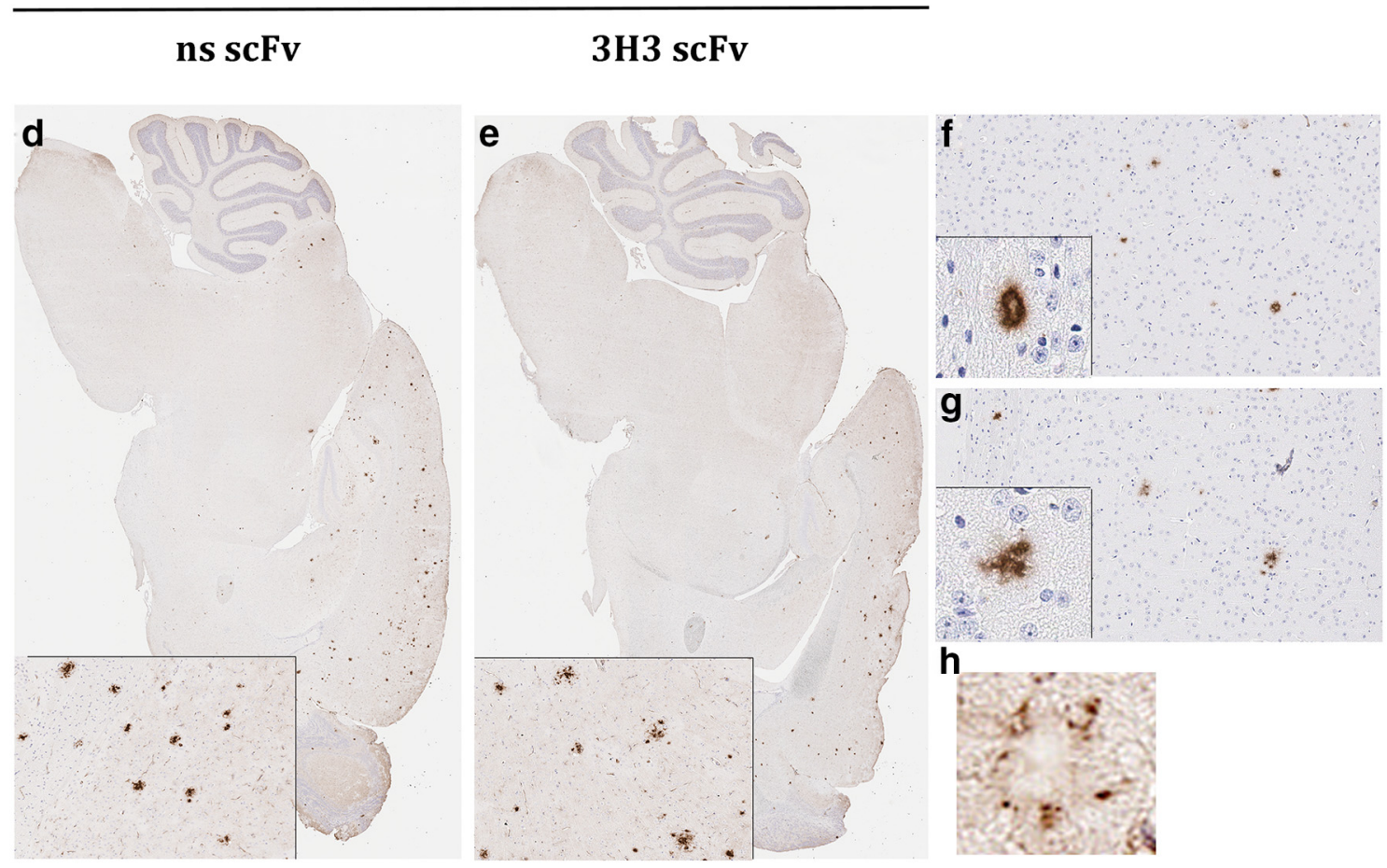

g

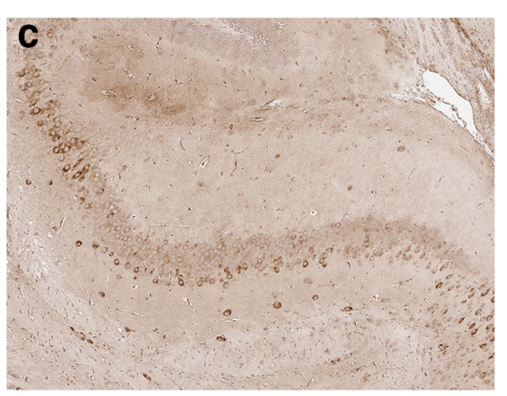

Ripa

SDS

FA

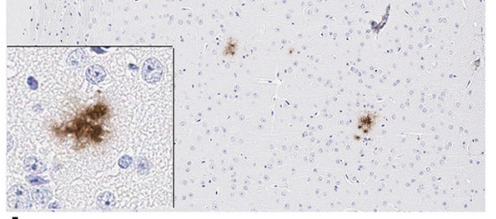

h

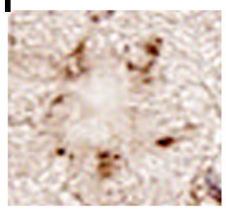

j
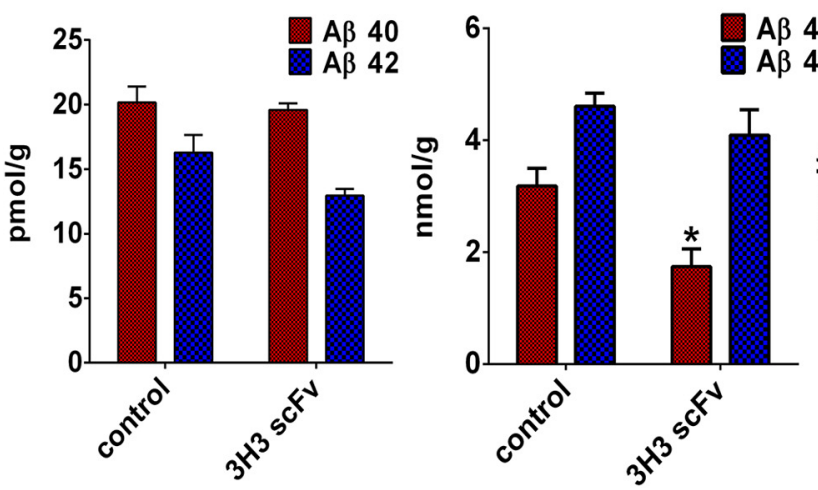

$A \beta$
$A \beta$ 42
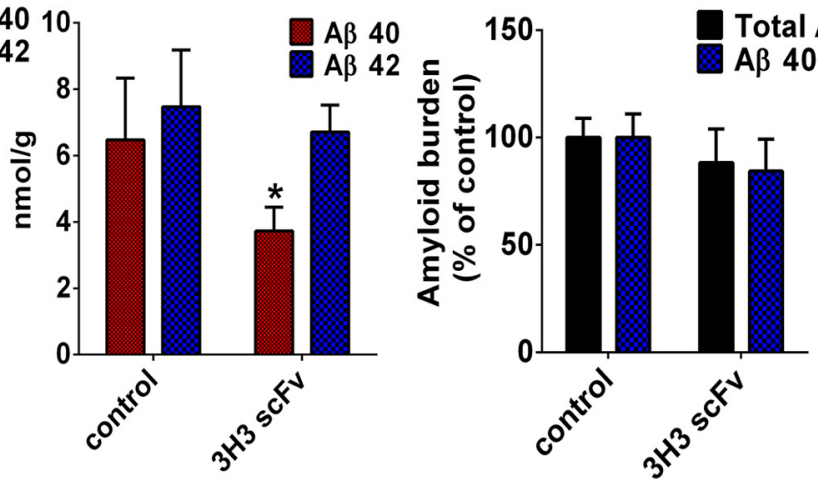

Figure 5. $3 \mathrm{H} 3 \mathrm{scFvs}$ attenuates $\mathrm{A} \beta$ deposition in 5 month-old CRND8 mice. Newborn CRND8 mice were injected ICV with AAV $3 \mathrm{H} 3 \mathrm{scFv}\left(4 \times 10^{10}\right.$ genomes/mouse). Control mice received PBS. Five months later, the mice were killed and analyzed. One hemibrain was used for immunohistochemistry and the other for biochemical analysis. scFv expression in the brain was detected by staining for the c-Myc tag. The photomicrographs are representative sections of groups of 7-10 mice: (a) PBS (b,c) 3H3 scFv. Magnification 10×. Representative brain sections from PBS (d, $\boldsymbol{f}$ ) or $3 \mathrm{H} 3 \mathrm{scFv}$ $(\boldsymbol{e}, \boldsymbol{g})$ injected mice were stained with pan- $\mathrm{A} \beta \mathrm{mAb}(33.1 .1)(\boldsymbol{d}, \boldsymbol{e})$ or the $\mathrm{A} \beta 40$ specific mAb (13.1.1) $(\boldsymbol{f}, \boldsymbol{g})$. Magnification $2 \times$ and $5 \times$ (insets $5 \times$ and $20 \times)$. (h) $3 \mathrm{H} 3$ scFv expression surrounding amyloid plaques was visualized by staining for $c-M y c$ tag. Magnification $20 \times$ (i) A $\beta 40$ and A $\beta 42$ levels in brain extracts solubilized with RIPA buffer, SDS, or formic acid (FA), analyzed by sandwich ELISA $n=5 .^{*} p<0.05$ vs control. (j) A $\beta$ plaque burden analysis was performed on three nonconsecutive sections from each mouse in the group. $n=7-10$. 
brain sections from PBS-injected (Fig. $5 d, f$ ) or pAAV-3H3 scFvinjected mice (Fig. $5 e, g$ ) with either a pan- $\mathrm{A} \beta \mathrm{mAb}$ (Fig. $5 d, e$ ) or an $\mathrm{A} \beta 40$-specific $\mathrm{mAb}$ (Fig. $5 f, g$ ). We did not observe clear differences in the number of plaques present. However, the plaque morphology in the pAAV-3H3 scFv-injected mice was more diffuse (Fig. $5 f, g$ ). In the injected mouse brains, the plaques were decorated by the $3 \mathrm{H} 3 \mathrm{scFv}$, as visualized by anti-c-Myc staining around the plaques (Fig. $5 h$ ).

We assessed the total amyloid burden by measuring amyloid $\mathrm{A} \beta$ levels in RIPA-soluble, SDS-soluble, and FA-soluble brain fractions by ELISA (Fig. $5 i$ ). A $\beta 40$ levels were significantly lower in the SDS and FA extracts from the AAV-3H3 scFv-injected mice, compared with the control mice, but a statistically significant change was not observed in $A \beta 42$ levels in the SDS and FA extracts or in the $\mathrm{A} \beta 40$ or $\mathrm{A} \beta 42$ levels in the RIPA-extracted fractions. Quantification of the total $A \beta 40$ plaque burden on brain sections of control and scFv-expressing mice also did not show a significant difference (Fig. $5 j$ ).

We extended these results by delivering the pAAV- $3 \mathrm{H} 3 \mathrm{scFv}$ in ADan mice, in which the Danish amyloid subunit comprising the last 34 aa of human $B R I_{2}$ is expressed under the control of the mouse prion protein promoter. ADan mice show significant intracellular and extracellular deposition of oligomeric forms of ADan, including vascular amyloid deposition, parenchymal ADan deposition, and amyloid associated gliosis (Vidal et al., 2009). We injected newborn ADan mice with $4 \mu \mathrm{l}$ of pAAV-3H3 $\mathrm{scFv}\left(10^{13}\right.$ genomes $\left./ \mathrm{ml}\right)$. Control mice were injected with PBS. Expression of scFv was confirmed by anti-c-Myc brain staining 3 weeks after injection in 3 mice and remaining mice were aged to 12 months. At that time, brains were harvested and effects of scFv on development of pathology were evaluated. Control mice developed significant Thio-S-positive CAA in the meninges, thalamus, and cerebellum, whereas $3 \mathrm{H} 3 \mathrm{scFv}$-expressing mice had less CAA pathology in these tissues (Fig. 6a). Quantification of reduction in Thio-S-positive total positive signal as well as the number of Thio-S-labeled blood vessels revealed statistically significant reductions in the $3 \mathrm{H} 3 \mathrm{scFv}$-expressing mouse brains (Fig. 6b).

Mutant ADan amyloid deposits in ADan mice can be visualized by binding with antibody 1700 (rabbit polyclonal; Vidal et al., 2009). In the control mice, typical staining was observed in the hippocampus as well as in the blood vessels in the cerebellum, whereas mice expressing $3 \mathrm{H} 3 \mathrm{scFv}$ had virtually no amyloid-like deposits in the hippocampus and less ADan-positive CAA in the cerebellum (Fig. 6c). Importantly, $3 \mathrm{H} 3 \mathrm{scFv}$ expression correlated with reduced astrocytosis in the brains of the mice, as demonstrated by decreased GFAP staining in the hippocampus, midbrain, and cerebellum (Fig. 6d).

\section{Discussion}

The $3 \mathrm{H} 3 \mathrm{mAb}$ is a human monoclonal antibody, cloned from a healthy subject, that binds multiple amyloids, regardless of the primary sequence of the protein subunits. The $3 \mathrm{H} 3$ demonstrated anti-amyloid activity in vitro and in three in vivo model systems. Therefore, the $3 \mathrm{H} 3$ recapitulates essential features of amyloid-binding IgGs previously identified in polyclonal IVIG (O’Nuallain et al., 2006; Britschgi et al., 2009; Dodel et al., 2011). Because $3 \mathrm{H} 3$ was identified by its recognition of JTO Ig LC and A $\beta 42$ amyloids, it represents just one of the many types of antiamyloid antibodies that may exist in IVIG. Nonetheless, the $3 \mathrm{H} 3$ demonstrates that potentially therapeutic features of IVIG can be embodied in a human mAb that may be adaptable for therapeutic use.
The $3 \mathrm{H} 3$ originated from a $\mathrm{CD} 27^{+}$peripheral blood $\mathrm{B}$ cell and has somatically mutated variable domains, indicating that it had undergone T-cell-dependent antibody affinity maturation and is therefore the product of the adaptive immune response. The amyloid-specific binding of the $3 \mathrm{H} 3 \mathrm{scFv}$ indicates that recognition of the conformational amyloid epitope occurs through the canonical CDR-binding domains, not Fc-mediated interactions, as has been reported for at least one amyloid protein (Huang et al., 1993). The observation that IgGs with similar features can be found in children, in addition to IVIG, suggests that IgG-binding conformational amyloid epitopes are the products of the normal immune response to amyloids (Baril et al., 2004).

In the live rat model of hippocampal LTP, $3 \mathrm{H} 3$ abrogated the synaptotoxicity of soluble $\mathrm{A} \beta$ oligomers contained in an $\mathrm{AD}$ brain extract. Soluble A $\beta$ species extracted from human brains are pathophysiologically relevant material for modeling key features of AD (Shankar et al., 2008). The ability of the $3 \mathrm{H} 3 \mathrm{mAb}$ to inhibit their toxicity on a living brain demonstrates one mechanism whereby naturally occurring, conformation-specific antibodies in IVIG may exert a protective function in AD. Murine conformation-specific mAbs have also shown activity in the rat model of A $\beta$ synaptotoxicity (Klyubin et al., 2008; O'Nuallain et al., 2011).

In the TgCRND8-transgenic mouse model of CNS A $\beta$ deposition, expression of the $3 \mathrm{H} 3 \mathrm{scFv}$ significantly reduced the levels of SDS- and FA-extractable $A \beta 40$, but had no statistically significant change in $A \beta 42$ levels. This selective effect on $A \beta 40$ is consistent with selective targeting of $A \beta$ amyloid because $A \beta 40$ is more selectively deposited in cored amyloid plaques, whereas $\mathrm{A} \beta 42$ deposits in both cored amyloid plaques and more diffuse immunoreactive deposits that are not congophilic. Indeed, a change in plaque morphology was noted in the mice expressing the $3 \mathrm{H} 3 \mathrm{scFV}$ because the plaques appeared less compact and more diffuse. The $3 \mathrm{H} 3 \mathrm{scFV}$ was observed to surround $\mathrm{A} \beta$ plaques in the brain, suggesting that it may inhibit amyloid formation by plaque binding. In brains of $\mathrm{AD}$ patients, colocalization of IgGs with $A \beta$ neuritic plaques has been observed and patients with high IgG plaque labeling had significantly reduced $\mathrm{A} \beta$ plaque burdens (Kellner et al., 2009).

In the FDD model of CAA deposition in ADan mice, $3 \mathrm{H} 3 \mathrm{scFv}$ expression reduced amyloid deposition and CAA while reducing inflammation-associated expression of GFAP. Others have shown that AAV delivery of an anti-amyloid scFv preferentially targeting $\mathrm{A} \beta 42$ oligomers can reduce $\mathrm{A} \beta 42$ in the hippocampus in the TgA $\beta$ PPswe/PS1dE9 mouse model of AD, although it exacerbates CAA (Kou et al., 2011). These different results may be attributable to particular binding properties of the scFvs and the use of different models. It is unlikely that the $3 \mathrm{H} 3 \mathrm{scFv}$ could induce glial clearance of $\mathrm{A} \beta$ because it lacks effector functions. Additional efforts to add effector functions, increase affinity, or increase the concentrations of the $\mathrm{scFv}$ in vivo may enhance its anti-amyloid activity. In any case, our data with the $3 \mathrm{H} 3 \mathrm{scFv}$ indicates that pan-amyloid scFv antibodies can attenuate deposition of different amyloids in vivo.

The finding that $3 \mathrm{H} 3$ bound to plate-immobilized monomeric $\mathrm{A} \beta$ in a direct ELISA may seem paradoxical given the strong evidence for its binding to a pan-amyloid conformational epitope; for example, binding to diverse amyloid oligomers and preferential binding to oligomeric $A \beta$ in competition binding studies. One explanation is that, when $\mathrm{A} \beta$ binds the $3 \mathrm{H} 3$ antibody, the bound $\mathrm{A} \beta$ has an amyloid-like conformation that was induced by plate immobilization (O’Nuallain et al., 2007; Szabo et al., 2010). The differential effects of $3 \mathrm{H} 3$ at different concen- 
a
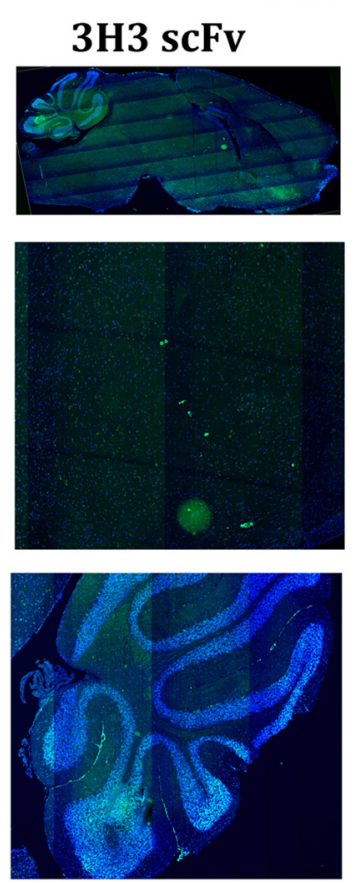

C
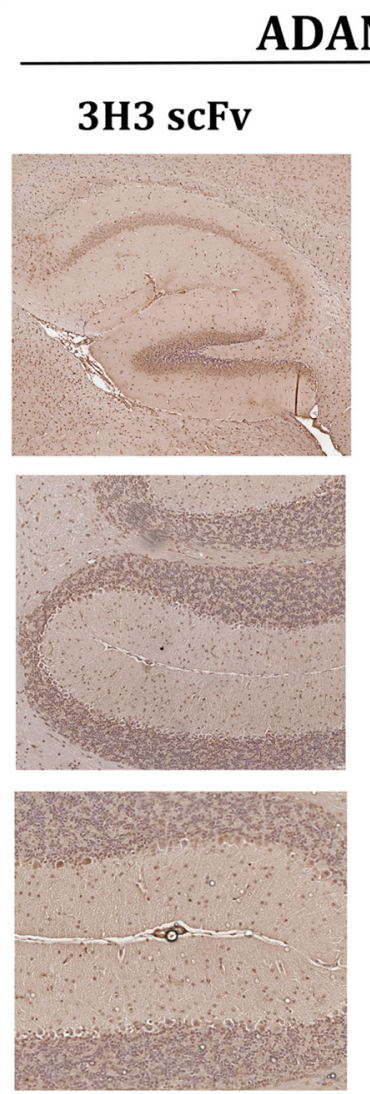

\section{control}
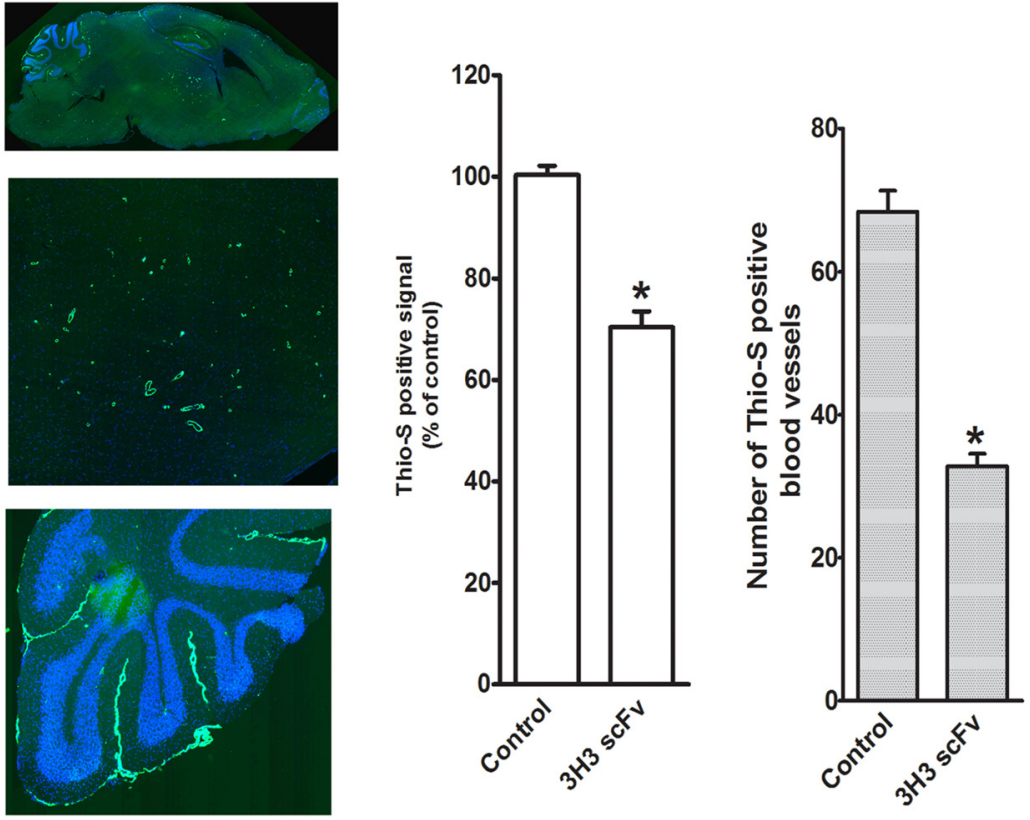

d
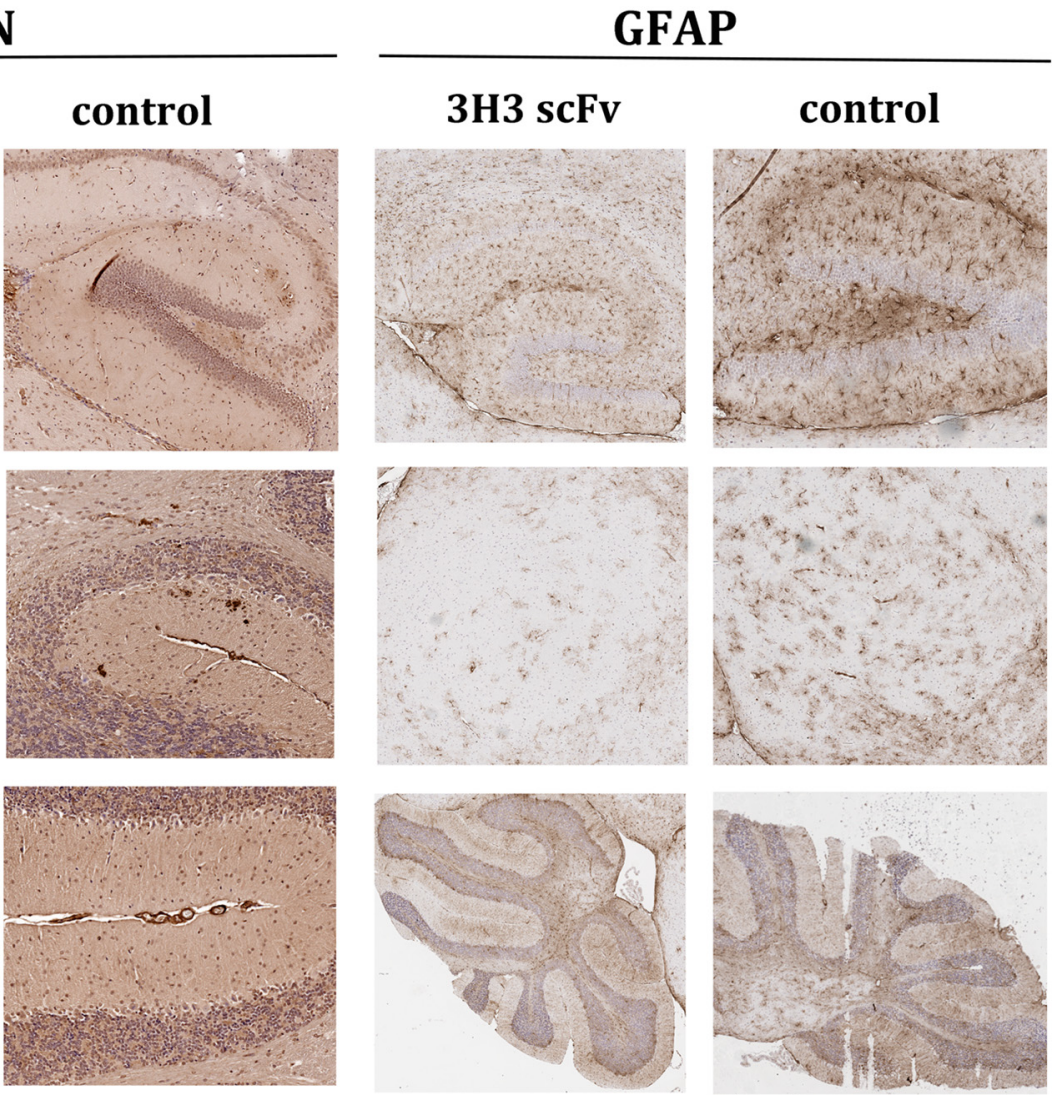

Figure 6. $3 \mathrm{H} 3 \mathrm{scFv}$ expression prevents development of pathology in ADan-transgenic mice. (a). Newborn ADan-transgenic mice were injected into cerebral ventricles with pAAV - $3 \mathrm{H} 3 \mathrm{scFv}$ ( $4 \times$ $10^{10}$ genomes/mouse) and killed at 12 months of age. (AA pathology in blood vessels was visualized with Thio-S in the hippocampus (top panels), thalamus (middle panels), and cerebellum (bottom) of mice injected with PBS or pAAV-3H3 scFv. (b) Quantification of fluorescence positive signal (left) and number of Thio-S positive blood vessels (right), showing decreases in the 3H3-scFv group compared with PBS-injected mice ( $n=5-7 /$ group). ${ }^{*} p<0.05, t$ test). Data are shown as the mean \pm SEM (c) An anti-ADan polyclonal antibody 1700 was used to detect ADan peptide accumulation in the hippocampus and cerebellar blood vessels of PBS treated and 3H3-scFv-expressing mice. (d). GFAP was analyzed by immunohistochemistry in brains of 3H3-scFv expressing mice, compared with age-matched controls, in hippocampus (top), thalamus (middle) and cerebellum (bottom). 
trations on $\mathrm{A} \beta$ and JTO amyloid formations provide indirect support for this assertion. At low concentrations, $3 \mathrm{H} 3$ delayed fibril formation but increased the total amount of amyloid formed, whereas at higher concentrations, amyloid formation was inhibited. It is possible that such effects could be explained by $3 \mathrm{H} 3$ converting monomeric $\mathrm{A} \beta$ and JTO into more uniform amyloid seeds, which could increase the lag time for aggregation but, once seeded, enable more uniform and efficient assembly. These $3 \mathrm{H} 3$-induced seeds could be structurally different from the uninhibited amyloid rections, resulting in slower reactions and different $\mathrm{ThT}$ reaction product yields. At higher $3 \mathrm{H} 3$ concentrations, sequestration of JTO and $\mathrm{A} \beta$ would lower concentrations of free monomer and inhibit overall amyloid formation.

The potent in vitro and in vivo anti-amyloid activities of $3 \mathrm{H} 3$ demonstrate that amyloids can be therapeutically targeted through epitopes that are independent of the primary sequence of the amyloid polypeptide. This offers the potential to treat amyloid diseases with mAbs that specifically bind toxic oligomeric forms and not to nontoxic, nonaggregated forms. A mAb with specificity for multimeric $\mathrm{A} \beta$, similar to the $3 \mathrm{H} 3$ in competition assays, reduced amyloid deposition and $\mathrm{A} \beta$ protofibril levels in a transgenic mouse model expressing both the Arctic and Swedish A $\beta$ mutations (tg-ArcSwe) (Englund et al., 2007; Lord et al., 2009).

In this study, $3 \mathrm{H} 3$ demonstrated activity in animal models intended to reproduce essential features of AD and FDD. Binding to patient-derived Ig LC amyloids in vitro and in pathological tissue sections further suggests that $3 \mathrm{H} 3$ may be helpful for treatment of other amyloid diseases such as primary amyloidosis, in which the LC amyloids are deposited in extracellular tissues that are accessible to the blood circulation. Proof-of-concept of the ability of a mAb specific for an amyloid epitope to clear LC amyloids in vivo has been established using a mouse model in which patient-derived amyloids were introduced by subcutaneous injection (Hrncic et al., 2000). mAb opsonization and macrophagedependent clearance of tissue-deposited amyloids has been demonstrated in a mouse model of amyloidosis induced by overexpression of serum amyloid P component (Bodin et al., 2010).

In conclusion, we have isolated an affinity matured human $\mathrm{mAb}$ that binds a pan-amyloid epitope and has binding specificity for aggregated amyloid forms. The mAb has anti-amyloid activities in vitro and in vivo, suggesting that naturally occurring anti-amyloid antibodies such as $3 \mathrm{H} 3$ may be protective and have potential as anti-amyloid therapeutics.

\section{References}

Adekar SP, Jones RM, Elias MD, Al-Saleem FH, Root MJ, Simpson LL, Dessain SK (2008a) A human monoclonal antibody that binds serotype A botulinum neurotoxin. Hybridoma 27:11-17. CrossRef Medline

Adekar SP, Jones RM, Elias MD, Al-Saleem FH, Root MJ, Simpson LL, Dessain SK (2008b) Hybridoma populations enriched for affinity-matured human IgGs yield high-affinity antibodies specific for botulinum neurotoxins. J Immunol Methods 333:156-166. CrossRef Medline

Adekar SP, Klyubin I, Macy S, Rowan MJ, Solomon A, Dessain SK, O'Nuallain B (2010) Inherent anti-amyloidogenic activity of human immunoglobulin gamma heavy chains. J Biol Chem 285:1066-1074. CrossRef Medline

Ban T, Hamada D, Hasegawa K, Naiki H, Goto Y (2003) Direct observation of amyloid fibril growth monitored by thioflavin T fluorescence. J Biol Chem 278:16462-16465. CrossRef Medline

Baril L, Nicolas L, Croisile B, Crozier P, Hessler C, Sassolas A, McCormick JB, Trannoy E (2004) Immune response to Abeta-peptides in peripheral blood from patients with Alzheimer's disease and control subjects. Neurosci Lett 355:226-230. CrossRef Medline

Besong-Agbo D, Wolf E, Jessen F, Oechsner M, Hametner E, Poewe W, Reindl M, Oertel WH, Noelker C, Bacher M, Dodel R (2013) Naturally occur- ring alpha-synuclein autoantibody levels are lower in patients with Parkinson disease. Neurology 80:169-175. CrossRef Medline

Bodin K, Ellmerich S, Kahan MC, Tennent GA, Loesch A, Gilbertson JA, Hutchinson WL, Mangione PP, Gallimore JR, Millar DJ, Minogue S, Dhillon AP, Taylor GW, Bradwell AR, Petrie A, Gillmore JD, Bellotti V, Botto M, Hawkins PN, Pepys MB (2010) Antibodies to human serum amyloid P component eliminate visceral amyloid deposits. Nature 468: 93-97. CrossRef Medline

Britschgi M, Olin CE, Johns HT, Takeda-Uchimura Y, LeMieux MC, Rufibach K, Rajadas J, Zhang H, Tomooka B, Robinson WH, Clark CM, Fagan AM, Galasko DR, Holtzman DM, Jutel M, Kaye JA, Lemere CA, Leszek J, Li G, Peskind ER, et al. (2009) Neuroprotective natural antibodies to assemblies of amyloidogenic peptides decrease with normal aging and advancing Alzheimer's disease. Proc Natl Acad Sci U S A 106: 12145-12150 CrossRef Medline

Campbell MJ, Zelenetz AD, Levy S, Levy R (1992) Use of family specific leader region primers for PCR amplification of the human heavy chain variable region gene repertoire. Mol Immunol 29:193-203. CrossRef Medline

Chakrabarty P, Rosario A, Cruz P, Siemienski Z, Ceballos-Diaz C, Crosby K, Jansen K, Borchelt DR, Kim JY, Jankowsky JL, Golde TE, Levites Y (2013) Capsid serotype and timing of injection determines AAV transduction in the neonatal mice brain. PLoS One 8:e67680. CrossRef Medline

Chishti MA, Yang DS, Janus C, Phinney AL, Horne P, Pearson J, Strome R, Zuker N, Loukides J, French J, Turner S, Lozza G, Grilli M, Kunicki S, Morissette C, Paquette J, Gervais F, Bergeron C, Fraser PE, Carlson GA, et al. (2001) Early-onset amyloid deposition and cognitive deficits in transgenic mice expressing a double mutant form of amyloid precursor protein 695. J Biol Chem 276:21562-21570. CrossRef Medline

Chiti F, Dobson CM (2006) Protein misfolding, functional amyloid, and human disease. Annu Rev Biochem 75:333-366. CrossRef Medline

Coronella JA, Telleman P, Truong TD, Ylera F, Junghans RP (2000) Amplification of IgG VH and VL (Fab) from single human plasma cells and B cells. Nucleic Acids Res 28:E85. CrossRef Medline

Cullen WK, Suh YH, Anwyl R, Rowan MJ (1997) Block of LTP in rat hippocampus in vivo by beta-amyloid precursor protein fragments. Neuroreport 8:3213-3217. CrossRef Medline

Diamandis EP (1988) Immunoassays with time-resolved fluorescence spectroscopy: principles and applications. Clin Biochem 21:139-150. Medline

Dodel R, Balakrishnan K, Keyvani K, Deuster O, Neff F, Andrei-Selmer LC, Röskam S, Stüer C, Al-Abed Y, Noelker C, Balzer-Geldsetzer M, Oertel W, Du Y, Bacher M (2011) Naturally occurring autoantibodies against beta-amyloid: investigating their role in transgenic animal and in vitro models of Alzheimer's disease. J Neurosci 31:5847-5854. CrossRef Medline

Du Y, Dodel R, Hampel H, Buerger K, Lin S, Eastwood B, Bales K, Gao F, Moeller HJ, Oertel W, Farlow M, Paul S (2001) Reduced levels of amyloid beta-peptide antibody in Alzheimer disease. Neurology 57:801-805. CrossRef Medline

Du Y, Wei X, Dodel R, Sommer N, Hampel H, Gao F, Ma Z, Zhao L, Oertel WH, Farlow M (2003) Human anti-beta-amyloid antibodies block beta-amyloid fibril formation and prevent beta-amyloid-induced neurotoxicity. Brain 126:1935-1939. CrossRef Medline

Englund H, Sehlin D, Johansson AS, Nilsson LN, Gellerfors P, Paulie S, Lannfelt L, Pettersson FE (2007) Sensitive ELISA detection of amyloid-beta protofibrils in biological samples. J Neurochem 103:334-345. Medline

Gu H, Zhong Z, Jiang W, Du E, Dodel R, Liu J, Farlow MR, Zheng W, Du Y (2014) The role of choroid plexus in IVIG-induced beta-amyloid clearance. Neuroscience 270:168-176. CrossRef Medline

Hrncic R, Wall J, Wolfenbarger DA, Murphy CL, Schell M, Weiss DT, Solomon A (2000) Antibody-mediated resolution of light chain-associated amyloid deposits. Am J Pathol 157:1239-1246. CrossRef Medline

Huang D, Martin M, Hu D, Roses AD, Goldgaber D, Strittmatter WJ (1993) Binding of IgG to amyloid beta A4 peptide via the heavy-chain hinge region with preservation of antigen binding. J Neuroimmunol 48:199203. CrossRef Medline

Hu NW, Nicoll AJ, Zhang D, Mably AJ, O’Malley T, Purro SA, Terry C, Collinge J, Walsh DM, Rowan MJ (2014) mGlu5 receptors and cellular prion protein mediate amyloid-beta-facilitated synaptic long-term depression in vivo. Nat Commun 5:3374. Medline

Janus C, Pearson J, McLaurin J, Mathews PM, Jiang Y, Schmidt SD, Chishti MA, Horne P, Heslin D, French J, Mount HT, Nixon RA, Mercken M, Bergeron C, Fraser PE, St George-Hyslop P, Westaway D (2000) A beta 
peptide immunization reduces behavioural impairment and plaques in a model of Alzheimer's disease. Nature 408:979-982. CrossRef Medline

Kayed R, Head E, Thompson JL, McIntire TM, Milton SC, Cotman CW, Glabe CG (2003) Common structure of soluble amyloid oligomers implies common mechanism of pathogenesis. Science 300:486-489. CrossRef Medline

Kellner A, Matschke J, Bernreuther C, Moch H, Ferrer I, Glatzel M (2009) Autoantibodies against beta-amyloid are common in Alzheimer's disease and help control plaque burden. Ann Neurol 65:24-31. CrossRef Medline

Kim J, Onstead L, Randle S, Price R, Smithson L, Zwizinski C, Dickson DW, Golde T, McGowan E (2007) Abeta40 inhibits amyloid deposition in vivo. J Neurosci 27:627-633. CrossRef Medline

Klein U, Rajewsky K, Küppers R (1998) Human immunoglobulin (Ig) $\mathrm{M}^{+} \mathrm{IgD}{ }^{+}$peripheral blood B cells expressing the CD27 cell surface antigen carry somatically mutated variable region genes: CD27 as a general marker for somatically mutated (memory) B cells. J Exp Med 188: 1679-1689. CrossRef Medline

Klyubin I, Walsh DM, Cullen WK, Fadeeva JV, Anwyl R, Selkoe DJ, Rowan MJ (2004) Soluble Arctic amyloid beta protein inhibits hippocampal long-term potentiation in vivo. Eur J Neurosci 19:2839-2846. CrossRef Medline

Klyubin I, Walsh DM, Lemere CA, Cullen WK, Shankar GM, Betts V, Spooner ET, Jiang L, Anwyl R, Selkoe DJ, Rowan MJ (2005) Amyloid beta protein immunotherapy neutralizes Abeta oligomers that disrupt synaptic plasticity in vivo. Nat Med 11:556-561. CrossRef Medline

Klyubin I, Betts V, Welzel AT, Blennow K, Zetterberg H, Wallin A, Lemere CA, Cullen WK, Peng Y, Wisniewski T, Selkoe DJ, Anwyl R, Walsh DM, Rowan MJ (2008) Amyloid beta protein dimer-containing human CSF disrupts synaptic plasticity: prevention by systemic passive immunization. J Neurosci 28:4231-4237. CrossRef Medline

Kou J, Kim H, Pattanayak A, Song M, Lim JE, Taguchi H, Paul S, Cirrito JR, Ponnazhagan S, Fukuchi K (2011) Anti-amyloid-beta single-chain antibody brain delivery via AAV reduces amyloid load but may increase cerebral hemorrhages in an Alzheimer's disease mouse model. J Alzheimers Dis 27:23-38. Medline

Lambert MP, Barlow AK, Chromy BA, Edwards C, Freed R, Liosatos M, Morgan TE, Rozovsky I, Trommer B, Viola KL, Wals P, Zhang C, Finch CE, Krafft GA, Klein WL (1998) Diffusible, nonfibrillar ligands derived from Abeta1-42 are potent central nervous system neurotoxins. Proc Natl Acad Sci U S A 95:6448-6453. CrossRef Medline

Lefranc MP, Giudicelli V, Kaas Q, Duprat E, Jabado-Michaloud J, Scaviner D, Ginestoux C, Clément O, Chaume D, Lefranc G (2005) IMGT, the international ImMunoGeneTics information system. Nucleic Acids Res 33: D593-597. Medline

LeVine H 3rd (1999) Quantification of beta-sheet amyloid fibril structures with thioflavin T. Methods Enzymol 309:274-284. CrossRef Medline

Levites Y, Jansen K, Smithson LA, Dakin R, Holloway VM, Das P, Golde TE (2006a) Intracranial adeno-associated virus-mediated delivery of antipan amyloid beta, amyloid beta40, and amyloid beta 42 single-chain variable fragments attenuates plaque pathology in amyloid precursor protein mice. J Neurosci 26:11923-11928. CrossRef Medline

Levites Y, Das P, Price RW, Rochette MJ, Kostura LA, McGowan EM, Murphy MP, Golde TE (2006b) Anti-Abeta42- and anti-Abeta40-specific mAbs attenuate amyloid deposition in an Alzheimer disease mouse model. J Clin Invest 116:193-201. Medline

Levites Y, Smithson LA, Price RW, Dakin RS, Yuan B, Sierks MR, Kim J, McGowan E, Reed DK, Rosenberry TL, Das P, Golde TE (2006c) Insights into the mechanisms of action of anti-Abeta antibodies in Alzheimer's disease mouse models. FASEB J 20:2576-2578. CrossRef Medline

Lord A, Gumucio A, Englund H, Sehlin D, Sundquist VS, Söderberg L, Möller C, Gellerfors P, Lannfelt L, Pettersson FE, Nilsson LN (2009) An amyloid-beta protofibril-selective antibody prevents amyloid formation in a mouse model of Alzheimer's disease. Neurobiol Dis 36:425-434. CrossRef Medline

Magga J, Puli L, Pihlaja R, Kanninen K, Neulamaa S, Malm T, Härtig W, Grosche J, Goldsteins G, Tanila H, Koistinaho J, Koistinaho M (2010) Human intravenous immunoglobulin provides protection against Abeta toxicity by multiple mechanisms in a mouse model of Alzheimer's disease. J Neuroinflammation 7:90. CrossRef Medline

Mengel D, Röskam S, NeffF, Balakrishnan K, Deuster O, Gold M, Oertel WH, Bacher M, Bach JP, Dodel R (2013) Naturally occurring autoantibodies interfere with beta-amyloid metabolism and improve cognition in a transgenic mouse model of Alzheimer's disease $24 \mathrm{~h}$ after single treatment. Translational Psychiatry 3:e236. CrossRef Medline
O’Nuallain B, Wetzel R (2002) Conformational Abs recognizing a generic amyloid fibril epitope. Proc Natl Acad Sci U S A 99:1485-1490. CrossRef Medline

O’Nuallain B, Hrncic R, Wall JS, Weiss DT, Solomon A (2006) Diagnostic and therapeutic potential of amyloid-reactive $\operatorname{IgG}$ antibodies contained in human sera. J Immunol 176:7071-7078. CrossRef Medline

O'Nuallain B, Allen A, Kennel SJ, Weiss DT, Solomon A, Wall JS (2007) Localization of a conformational epitope common to non-native and fibrillar immunoglobulin light chains. Biochemistry 46:1240-1247. CrossRef Medline

O’Nuallain B, Acero L, Williams AD, Koeppen HP, Weber A, Schwarz HP, Wall JS, Weiss DT, Solomon A (2008) Human plasma contains crossreactive Abeta conformer-specific IgG antibodies. Biochemistry 47: 12254-12256. CrossRef Medline

O’Nuallain B, Freir DB, Nicoll AJ, Risse E, Ferguson N, Herron CE, Collinge J, Walsh DM (2010) Amyloid beta-protein dimers rapidly form stable synaptotoxic protofibrils. J Neurosci 30:14411-14419. CrossRef Medline

O’Nuallain B, Klyubin I, Mc Donald JM, Foster JS, Welzel A, Barry A, Dykoski RK, Cleary JP, Gebbink MF, Rowan MJ, Walsh DM (2011) A monoclonal antibody against synthetic Abeta dimer assemblies neutralizes brainderived synaptic plasticity-disrupting Abeta. J Neurochem 119:189-201. CrossRef Medline

Relkin N (2014) Clinical trials of intravenous immunoglobulin for Alzheimer's disease. J Clin Immunol 34:S74-S79. Medline

Relkin NR, Szabo P, Adamiak B, Burgut T, Monthe C, Lent RW, Younkin S, Younkin L, Schiff R, Weksler ME (2009) 18-Month study of intravenous immunoglobulin for treatment of mild Alzheimer disease. Neurobiol Aging 30:1728-1736. Medline

Shankar GM, Li S, Mehta TH, Garcia-Munoz A, Shepardson NE, Smith I, Brett FM, Farrell MA, Rowan MJ, Lemere CA, Regan CM, Walsh DM, Sabatini BL, Selkoe DJ (2008) Amyloid-beta protein dimers isolated directly from Alzheimer's brains impair synaptic plasticity and memory. Nat Med 14:837-842. CrossRef Medline

Shevchenko A, Wilm M, Vorm O, Mann M (1996) Mass spectrometric sequencing of proteins silver-stained polyacrylamide gels. Anal Chem 68: 850-858. CrossRef Medline

St-Amour I, Paré I, Tremblay C, Coulombe K, Bazin R, Calon F (2014) IVIg protects the 3xTg-AD mouse model of Alzheimer's disease from memory deficit and Abeta pathology. J Neuroinflammation 11:54. CrossRef Medline

Sudduth TL, Greenstein A, Wilcock DM (2013) Intracranial injection of Gammagard, a human IVIg, modulates the inflammatory response of the brain and lowers Abeta in APP/PS1 mice along a different time course than anti-Abeta antibodies. J Neurosci 33:9684-9692. CrossRef Medline

Szabo P, Mujalli DM, Rotondi ML, Sharma R, Weber A, Schwarz HP, Weksler ME, Relkin N (2010) Measurement of anti-beta amyloid antibodies in human blood. J Neuroimmunol 227:167-174. CrossRef Medline

Urashima M, Chauhan D, Uchiyama H, Freeman GJ, Anderson KC (1995) CD40 ligand triggered interleukin-6 secretion in multiple myeloma. Blood 85:1903-1912. Medline

Vidal R, Barbeito AG, Miravalle L, Ghetti B (2009) Cerebral amyloid angiopathy and parenchymal amyloid deposition in transgenic mice expressing the Danish mutant form of human BRI2. Brain Pathol 19:58-68. CrossRef Medline

Wall J, Schell M, Murphy C, Hrncic R, Stevens FJ, Solomon A (1999) Thermodynamic instability of human lambda 6 light chains: correlation with fibrillogenicity. Biochemistry 38:14101-14108. CrossRef Medline

Walsh DM, Klyubin I, Fadeeva JV, Cullen WK, Anwyl R, Wolfe MS, Rowan MJ, Selkoe DJ (2002) Naturally secreted oligomers of amyloid beta protein potently inhibit hippocampal long-term potentiation in vivo. Nature 416:535-539. CrossRef Medline

Ylera F, Harth S, Waldherr D, Frisch C, Knappik A (2013) Off-rate screening for selection of high-affinity anti-drug antibodies. Anal Biochem 441: 208-213. CrossRef Medline

Zhang X, Sun XX, Xue D, Liu DG, Hu XY, Zhao M, Yang SG, Yang Y, Xia YJ, Wang Y, Liu RT (2011) Conformation-dependent scFv antibodies specifically recognize the oligomers assembled from various amyloids and show colocalization of amyloid fibrils with oligomers in patients with amyloidoses. Biochim Biophys Acta 1814:1703-1712. CrossRef Medline

Zhao M, Wang SW, Wang YJ, Zhang R, Li YN, Su YJ, Zhou WW, Yu XL, Liu RT (2014) Pan-amyloid oligomer specific scFv antibody attenuates memory deficits and brain amyloid burden in mice with Alzheimer's disease. Curr Alzheimer Res 11:69-78. CrossRef Medline 